\title{
Evolution of Outrigger Structural System: A State-of-the-Art Review
}

\author{
B. G. Kavyashree ${ }^{1} \cdot$ Shantharam Patil ${ }^{1}\left[\right.$ ] Vidya S. Rao $^{2}$
}

Received: 5 April 2021 / Accepted: 12 August 2021 / Published online: 25 August 2021

(C) The Author(s) 2021

\begin{abstract}
This paper presents the development of the outrigger structural system from the conventional outrigger to damped outrigger concepts. Outrigger structural system development from the conservative design as a rigid connection to a virtual connection with passive control, active control system, semi-active control system to hybrid control system is deliberated. Following brief overviews on history of outriggers, types of the outrigger, analysis of tall buildings without outriggers, formulation of equations for outrigger structure to simplify analysis are elaborated. Different approach to locate optimum positioning of outriggers in tall structure is elucidated. Analysis of outrigger to study its behavior in high-rise buildings using different methods is stated, and review on the damped outrigger system is explicated. This paper tries to highlight the advantages of outrigger structure with semi-active control and performance enhancement of the outrigger system with the effective devices, and enhanced results are also depicted. This review also paves a way for the new area of research in structural control with the incorporation of smart devices and smart technology.
\end{abstract}

Keywords Outrigger $\cdot$ Tall building $\cdot$ Dampers $\cdot$ Controllers $\cdot$ Structural response $\cdot$ Semi-active

\section{Introduction}

Today, increase in the worldwide population and the present trend of people moving toward cities has increased the scarcity of living space within cities which in turn demands the small space occupancy with a large population. This stimulates the demand for the ratio of small space to the large tenancy and triggering the construction of tall slender skyscrapers. In modern cities, tall buildings are a common prospect, as they proffer a high ratio of floor space per area of land, especially in those countries where land is inadequate. Tall buildings are also, arguably, a sign of a city's economic loftiness, and these structures are always prone to lateral forces like wind and earthquake. Unpredictable wind action can cause oscillatory activities and influence an extensive range of responses in building occupants, mild discomfort

Shantharam Patil

patil.s@manipal.edu

1 Manipal School of Architecture and Planning, Manipal Academy of Higher Education, Manipal, Karnataka 576104, India

2 Department of Instrumentation and Control Engineering, Manipal Institute of Technology, Manipal Academy of Higher Education, Manipal, Karnataka 576104, India to acute nausea, buildings become undesirable is elucidated by Smith [1]. The risk associated with tall buildings for seismic ground motion is very high since all tall buildings often accommodate thousands of occupants, and because of the unpredictable nature of earthquakes, particular attention has to be given to the design. It is conceivable that the structural collapse of such buildings can lead to disasters of unacceptable proportions. Preliminary analysis to find the natural frequency, mode shapes, and primary structural parameters is important in design, where most of the time the approximate methods are used like continuum method by considering Euler-Bernoulli or Timoshenko beam theory. Rahgozar [2] has introduced the novel approximate method in mathematical modeling of structure to find the preliminary structural parameter based on the energy method and Hamilton's principle. There is a need to introduce novel and simplified methods for the preliminary design approaches in structural system. Another important topic is the resistance of lateral forces that includes wind and earthquake forces that are dominantly considered in design of structures. Various structural systems have been introduced in tall buildings to overcome the lateral and vertical loads. These structural systems are divided into exterior and interior structural systems. The exterior structural systems such as the tube, framed tube, braced tube, bundled tube, tube-in-tube, diagrid, space truss, 
super-frame, and exoskeleton are explicated by the author in the article $[3,4]$ as shown in Fig. 1.

The interior structural systems are the moment-resisting frame, braced frames, concentrically braced frames, shear walls, rigid frame, frame tube, braced tube, bundled tube, and outrigger systems that can be used to enhance the lateral resistance in tall buildings as presented by Choi et al. [5] as shown in Fig. 2. Because of innovation of new design concepts and construction technologies, massive structures are being constructed across countries in their major cities, such as Taipei 101 in Taiwan, Shanghai's World Finance Center in China, Petronas Twin Towers in Malaysia, and the ultimate skyscraper, Burj Dubai, with a final projected height of more than $800 \mathrm{~m}$ is presented by the article [6] including the antenna is presented by the article [7], Fig. 3 represents world's tallest building with the height and name of the building [8]. Alhaddad et al. [9] has given a comprehensive introduction on outrigger usage in the tall building; detailing about building name, location, height, material, and outrigger usage is tabulated in the study.
Modernization toward the gigantic structures toward sky and preference to the most lightweight structure have increased risk of flexibility and probably diminished damping can lead the structure to become more susceptible to wind action [4]. To meet this requirement, the structure is designed to meet the requirements of ultimate strength and serviceability drift, but the structure is not free from levels of motion that can cause serious discomfort to its occupants. Therefore, there is a need to control the structure for structural safety and its occupants.

Rigorous research has been carried out to use smart systems for smart structures to quantify a building's acceleration to ensure that the building remains serviceable without causing disturbing motions to its occupants is presented in the article [10]. Simple methods for the structural analysis are needed; so Alavi et al. [11] developed a framework for combined structural and control optimization considering structural mass and linear quadratic regulator performance index as objectives. This approach combined structural and control variables as a single objective function linearly,

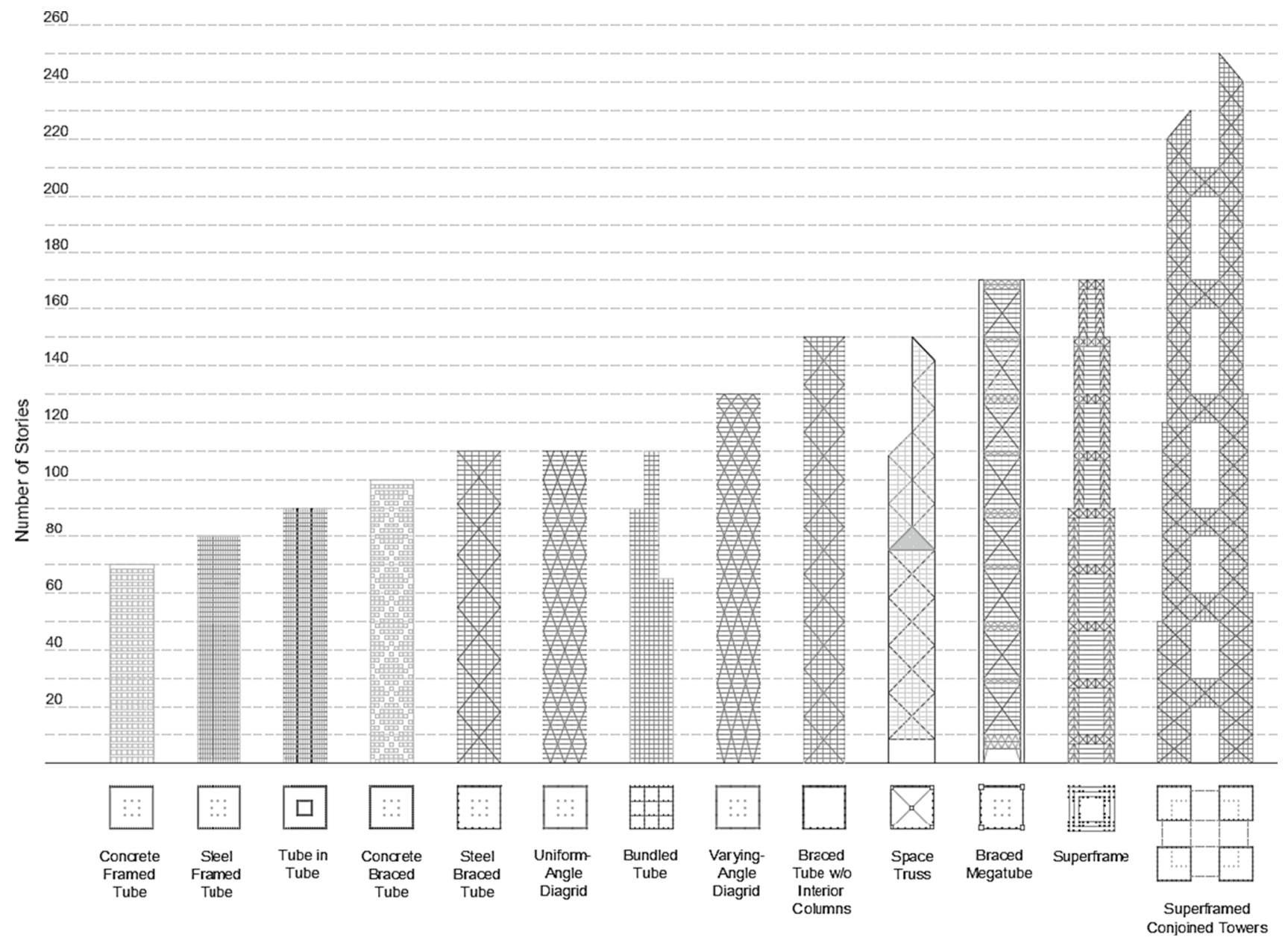

Fig. 1 External structural system [4] 


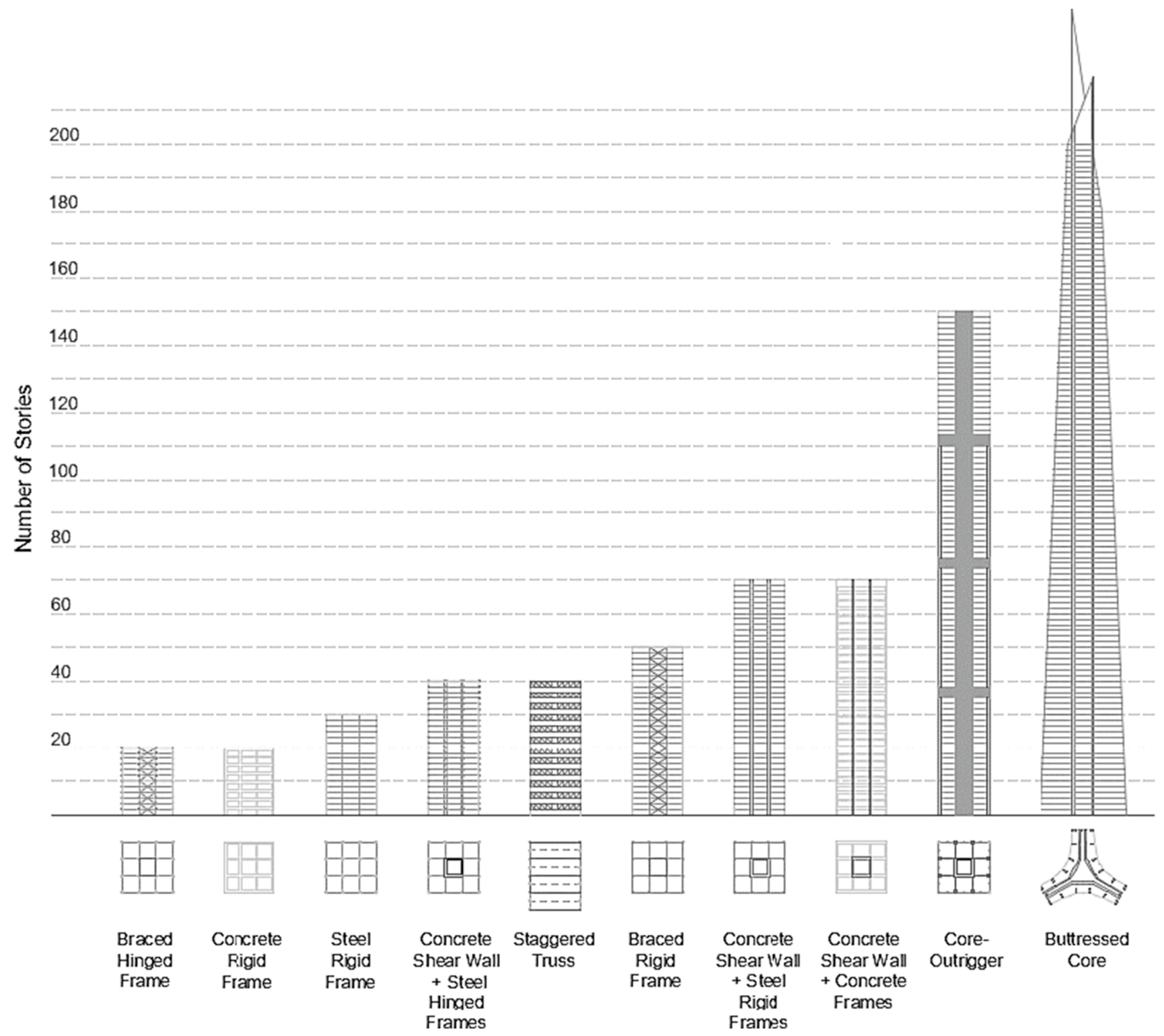

Fig. 2 Interior structures [4]

and the variable neighborhood search (VNS) metaheuristic method was adopted because of complexity. This combined method adopted by the authors in [11] delivers superior dynamic performance compared to the sequentially optimized cases. Research needs to be developed for finding the structural forms and effective ways to reduce uncontrolled lateral forces.

Some of the research has the core wall system that performs effectively in the reduction in structural responses like story drift, displacement, acceleration, etc., for the wind and earthquake loads as stated by authors in [12]. The core systems themselves offer enough confrontation to the overturning, but drift increases approximately to the cube of the height of the building [12]. Therefore, the height of the building makes the core wall system inefficient, and when the building height increases, stiffness of the core decreases, becomes insufficiently stiff to the wind load, and fails to bring down the wind drift to an acceptable limit [13]. To stabilize the tall structure, the concept of outriggers was introduced which was earlier used in canoes to stabilize it; so that the same behavior is mimicked in tall structural control. Outriggers are the stiff beam that connects the core of the structure to the perimeter column which has the advantage of mitigating the movement of the core, in turn, reduces the drift at the top floor in comparison with the structure without outriggers as stated in [5]. Ho [14] has provided a review on the concept of the outrigger system, optimum topology in construction, and its application in structural control. So in 


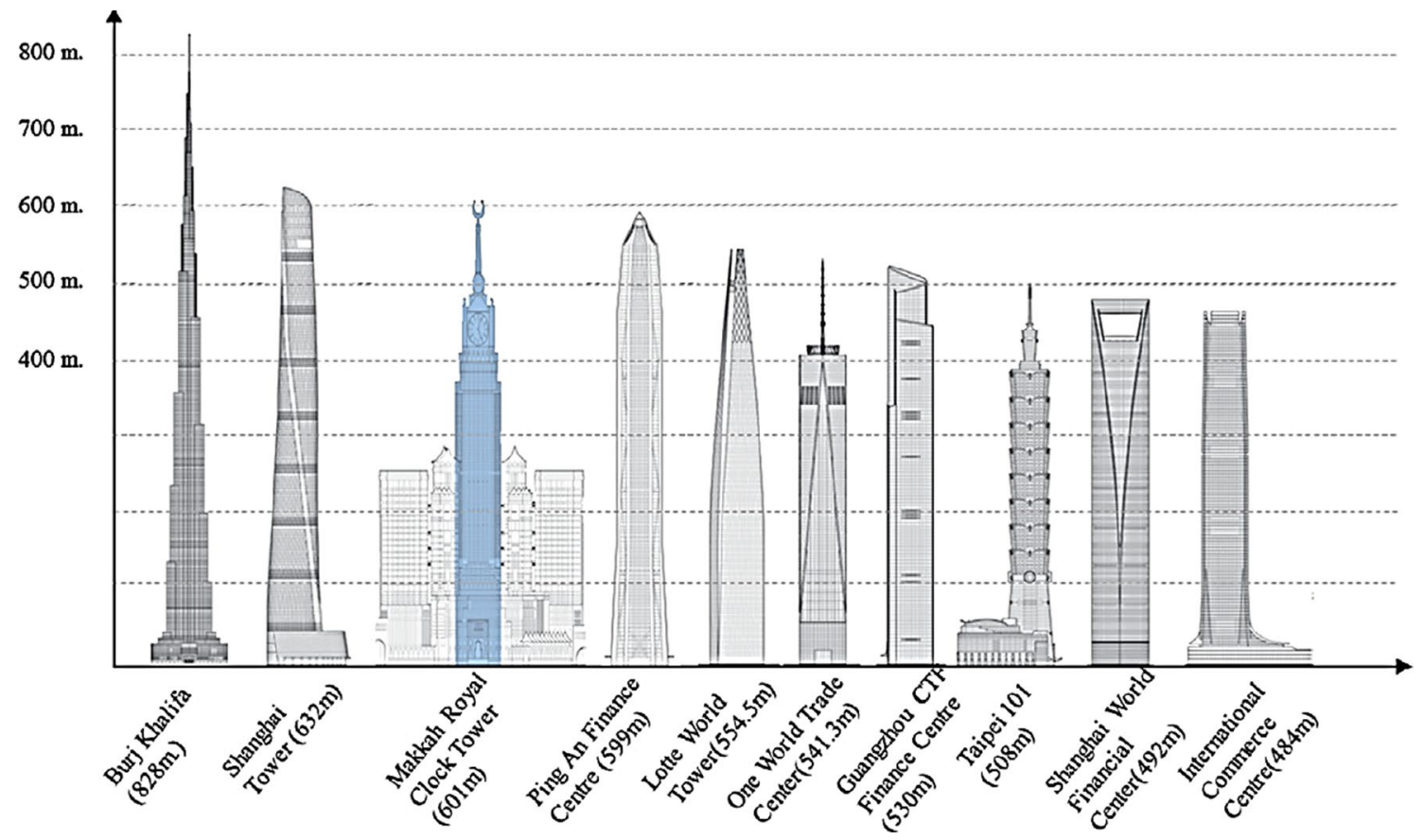

Fig. 3 Comparative heights of world's tallest buildings [8]

this study, a brief evolution of the outrigger structure over the period is discussed in Sect. 2, and developments of outrigger structural systems from tall buildings to the recent concept of damped outrigger in the structural control involving smart devices are explicated in Sect. 3.

\section{Overview of Outrigger Structure}

The concept of the outrigger started from its use in canoes. The archeological evidence shows that Austronesia's migrated from Southeast Asia sometime between 40,000 and 30,000 years ago. This was during the last ice age of the Pleistocene Era, which started 70,000 years ago and ended 10,000 years ago. This outrigger was introduced for rollover stabilization of canoes, and its concept is explained in terms of feedback mechanism. The feedback mechanism criteria are satisfied, i.e., it enhances the roll stability of the canoe, it provides negative feedback, it is a separate element from the canoe. Figure 4 shows canoes with outriggers. The main hull of the canoes with outrigger will be narrow compared to the plank-built vessel as stated in the article [15]. This concept of outrigger present in canoes system also can be used for other systems which require the roll stability. Thus, outrigger can be used for the tall slender structural system where the core with the outrigger will mitigate the top drift and stabilize the overturning moment.

Historically, outriggers are used for the slimmer system as in the case of canoes to resist wind, it can be considerably used in skyscrapers which are having a slender and tall core that is affected by the wind. The use of outriggers in highrise buildings started about 5 decades ago as stated in the article [15]. Smith and Salim [16] stated that the first outrigger building was designed by Barbacki which was 47 stories, Place Victoria Building in Montreal Canada, completed in 1962. This outrigger braced structure acts as a single structure in a combination of outriggers connected to the core wall and perimeter column when excited by lateral loads
Fig. 4 a Single outrigger canoe, b Double outrigger canoe [7] (a)

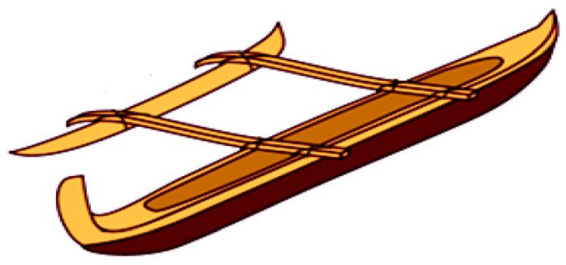

(b)

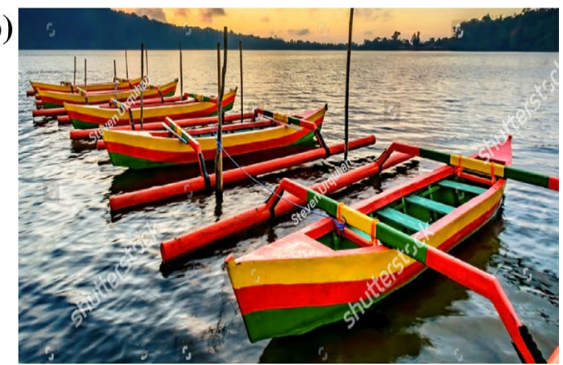


like wind and earthquake. Likewise, in the cases where the core of tall buildings cannot handle the lateral load alone, outriggers reduce the moment in the core by transferring part of it to the outer columns in the form of axial forces consisting of compression-tension couples as stated in the article [3]. Eventually, the core will no longer act as a pure cantilever. A belt truss can be used to help to distribute the forces to a larger number of columns and to reduce the differential corners that can support the outriggers as well. Even though outriggers are internal structures, the contribution to belt trusses and mega columns represents a large planner spread of the building stresses. Another advantage of an outrigger structure is that closely spaced columns are not needed which allows flexibility in meeting building functional requirements as presented in an article [17]. Previous studies demonstrate a possibility that designing the belt truss is not only to resist the lateral load but to mitigate possible disproportionate collapse caused by extreme events. Other research works state the usage of buckling restrained bracing members in an outrigger to increase the energy dissipation besides the extra stiffness as explained in [18]. Since outriggers are added to the dual structural system (shear walls and frames) aiming for extra stiffness, the location of those outriggers will have a major impact on the whole building behavior as stated by authors in the article [19]. Therefore, most of the studies were oriented toward finding the optimal location of the outriggers in the tall building against applied loads using all possible approaches as stated in [19]. Taranath [20] stated that by the introduction of outriggers in the structure, its stiffness increases by 20 to 30 percent. Thus, in the massive structures, outriggers have been introduced which can be constructed out of reinforced concrete or steel-braced core which are linked to the perimeter column by a flexural stiff horizontal beam at an optimal location. The introduction of these outriggers increases the lateral flexural resistance to the building, it does not increase the shear stiffness and the core itself will carry all the lateral shear forces as illustrated in [21]. The advantages of outriggers are presented in article [22], they will decrease the lateral moment of the structure, the overturning moment of the core is reduced which will reduce the uplifting of the core, which will decrease foundation cost. In a rectangular plan of the structure, the outrigger adds the interior gravity column as lateral load resisting elements intern the economy of the structure can be achieved. Also, the outrigger can be in many structural forms like the tube-in-tube, frame tube, core wall, and shear wall system with the outer column. The addition of an outrigger in the system will increase the stiffness of the system; will also make axial stress distribution in a column that leads to a decrease in shear lag effect as stated in the article [9]. Damped outrigger concept also has advantages like reducing force induced in the component of control elements in the structure and involves in reducing material usage in construction adding to the economy. Article [9] states few discomforts like differential shorting and no repetitive construction sequence because of the outrigger at the different levels and construction practice sluggish down. As the number of outriggers increases in tall buildings, its construction cost increases with the difficulty of the construction sequence. There are some other disadvantages like irregular stiffness is distributed within the floors of the structure because of outrigger that produces weak stories near the outrigger levels.

Considering all advantages and disadvantages of outrigger structure, there are different types of outrigger depending on the structural material used, the connection of external and internal systems, and depending on its response [9]. Depending on structural material, there are steel outrigger, concrete outrigger, and composite outrigger. Depending on the connection and response of the outrigger, there are rigid (conventional) outrigger, flexible outrigger, damped outrigger, yielding outrigger, offset outrigger, and virtual outrigger [9]. Article [23] states that the conventional outrigger concept is based on the planar concept with the interactions between the core walls, the outrigger arms, and the exterior columns. In this system, outriggers are directly connected to the core shear wall or braced frames at the core and the perimeter column at the exterior end. This system when imposed with lateral loading acts along the plane of the outrigger bent, the bending of the core rotates the stiff outrigger arms that cantilever from it, inducing tension in the upwind column and compression in the downwind column. These column forces, acting at the extremities of the outrigger arms, form a couple that restrains the bending and deflection of the core. Article [23] states that when outriggers are not placed in the plane with the core walls, but it adopts all the advantages, and by reducing some of the disadvantages of conventional outriggers a new type of outrigger is produced, called an offset outrigger. The offset outrigger states that the offset is taken from the core wall, and the outrigger is placed horizontally within the floor plan. Eom et al. [24] analyzed the virtual outrigger as distributed belt wall system to comprehend the behavior of the structure. The article [24] has made a study on belt walls made of the reinforcing method using high-strength pre-stressing strands subjected to high shear demand, and compression field theory was used to find the shear strength of pre-stressing strands. The authors concluded that the drift of the structure is reduced as effectively as conventional belt and outrigger systems with the correct arrangement and number of belt walls. The output recommends that the shear design of the pre-stressing strands belt walls depends on the cracking strength; its shear resistance can be increased by using an increased pre-stressing and reinforcing ratio [24]. Figure 5 shows a typical floor plan of the conventional outrigger, offset outrigger, and alternative offset outrigger. 
Fig. 5 Plan of a Typical floor plan, b Conventional outrigger, c Offset outrigger, d Alternative offset outrigger [23]
Core Walls

(a)

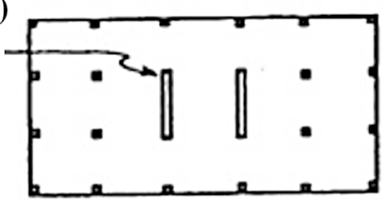

(c)

Outriggers

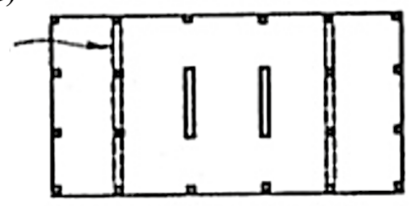

(b)

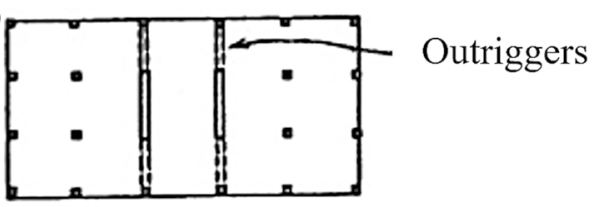

(d)

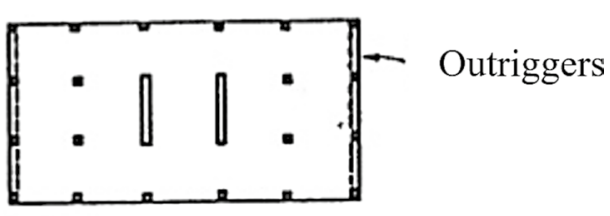

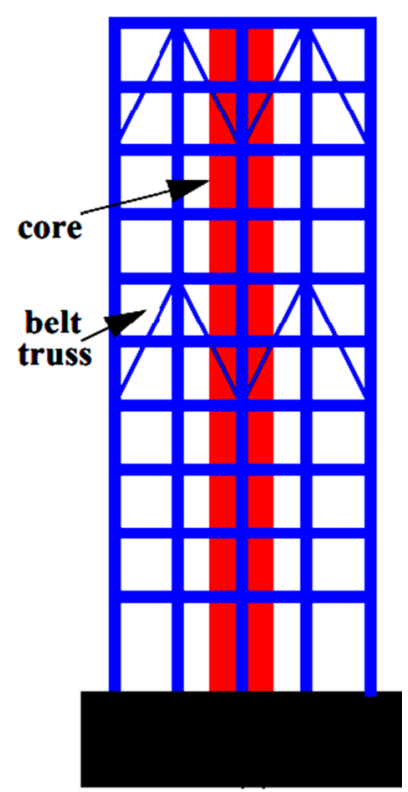

Fig. 6 Virtual outrigger system using belt trusses [25]

As seen in conventional outrigger, there is a direct connection between the core, outrigger, and peripheral column, this direct connection is not seen in the virtual outrigger concept but a diaphragm is used to transfer overturning moment from the core, which is usually very sturdy and stiff in their plane, to transfer moment in the form of a horizontal couple from the core to trusses or walls that are not connected directly to the core. This is achieved by providing belt trusses or belt walls for full depth, continuously, around the perimeter of an outrigger level as stated in [25] and act together with the top and bottom structural diaphragm of the outrigger level as shown in Fig. 6.

Virtual outriggers provide an advantage because the direct connection between the core and outrigger is eliminated as stated in [23]. The outrigger structural evolution is briefly elaborated by the different researchers in Sect. 3 .

\section{Development of Outrigger Structural System from Tall Buildings}

A tall structure with the outrigger and belt trusses has proved to be adequate in mitigating the story drift, base shear, and base moment of the core. Therefore, research has been undertaken, the study of outrigger structural behavior under lateral load. As per the study undertaken by different researchers, the review on outrigger structural system can be broadly classified as

- Analysis of tall building without outriggers by different approaches

- The empirical formulation for outrigger structural system

- Optimum positioning of outriggers by various methods

- Analysis of outrigger structure by different techniques

- Damped outrigger concept

Tall buildings came into existence in the late nineteenth century, which was the economic symbol of the city. These tall buildings development from a small- and medium-sized structure has taken place in the cities because of the population to the floor area ratio. The evolution of tall buildings and the technology behind the development of tall buildings are briefly discussed in the introduction. Review on tall buildings is a vast topic with the inclusion of the tall building evolution, classification of building structural system, the material used for construction, height criteria, advantage and disadvantage of the tall structural system. Ali and Moon [3] illustrated all above consideration of building with damping strategy for a structural system like an active system which includes an active mass damper, active liquid column damper, and passive system which includes tuned mass damper further subdivided as pendulum type, sliding type, bearing mounted type and tuned liquid damper further subdivided as tuned sloshing damper, tuned liquid column damper. The authors also described the implementation of these devices in the tall structural system and further explained the new contemporary structural forms and their 
concept, their advantages, and disadvantages, their material, topology and size, number of stories, and scale of real example buildings that are coated for all the classification of structures with the location, and specification is also presented by the article [26, 27]. The shortcoming of the tall building led to structural control practice to safeguard the skyscrapers battered by uncertainty. Soong and Spencer [28] presented state-of-the-art and state-of-the-practice review, alongside article $[29,30]$ presented a state-of-the-art review on structural control systems including implementation of the passive and active control system in all real structural details with name, location, year, the scale of the building, control system, number and mass of control system and actuation mechanism is specified. This is the general review which includes the passive, active, and semi-active structural control with a description of semi-active dampers like variable orifice fluid dampers, variable stiffness devices, controllable friction devices, smart tuned mass dampers, and tuned liquid dampers, controllable fluid dampers, and controllable impact dampers. Initially, tall buildings are stabilized by a passive protective system by using the bracing systems of different combinations for the mitigation of structural response like displacement, inter-story drift, shear response, etc. To illustrate the passive control, article [31] adopted a genetic algorithm to determine optimum bracing system, by using $X, V$, and $Z$ bracings with constraints as strength and serviceability. Authors proved with a design example that $V$ and $Z$ bracing do not show much lateral stiffness as $X$ bracing. As the height of the building increases, the bracing system shows sluggish resistance to lateral loading, therefore, for tall building response control, alternative methods are presented by a different researcher. So to improve the tall structural resistance toward lateral load, the stiffness parameter and damping of the structure were studied in [32]; presented a novel probabilistic damping model to explain amplitudedependent damping of tall buildings. This method showed that height is not a good parameter to decide to damp instead it is lateral deformation response; hence, the structural response of the tall building is important in deciding the damping capacity of tall buildings. Initially, to increase the damping of the structure, the passive damping system was designed, its mechanism depends on structural response. A passive system does not require an external power source for its works and it is easy to maintain which makes it reliable and economical. The passive damping also includes the dampers like viscous dampers, tuned mass dampers, friction devices, metallic yield devices, tuned sloshing dampers, and tuned column dampers, these dampers are expounded in the article [10]. Many researchers studied tuned liquid damper (TLD) but article [33] studied the sloping bottom TLD with the slope of the bottom end at 200, 300 and 450 for a different type of structure, mass ratio, and depth ratio. The author found that the slope in the bottom of TLD will reduce the structural response more than a flat bottom TLD. Another passive device exercised in the article [34] was tuned mass damper (TMD) in multi-story buildings which were analyzed for time history analysis in ETABS with TMD and without TMD which are excited about earthquake ground motion, and the performance comparison is made by placing it at the top of the building. Results depict that TMD reduces structural response better when placed at the top of the building. Giaralis and Petrini [35] further used a tuned mass-damper-inerter to upgrade the performance of existing TMD in benchmark buildings without changing the attached mass to reduce displacement. These passive devices provide control to a building to a certain extend which cannot adapt to all the uncertainty because its behavior cannot be manipulated, as it is installed permanently to the structure. TMD has some disadvantages like the requirement of huge mass and more space for installment and requires an adjustment of the frequency to fine-tune its performance in agreement with a natural frequency of the structure. To overcome the limitations of the passive system, semi-active control has been adapted instead of active control because of its reliability like passive and adaptability like active devices. A set of semi-active dampers is used in the article [36] for a comparative study to reduce the response of the structure by using different control laws and dampers like magnetorheological (MR) dampers and variable stiffness tuned mass dampers. The author used optimal static output feedback control, linear quadratic Gaussian, and Passive-on controllers to actuate dampers and performance is compared in reducing seismic response mitigation. Another semi-active device stated in [37], modeled a 76-story benchmark building (as described in detail by the article [38]) with a semiactive tuned mass damper (STMD), consists of MR damper controlled by a multi-objective genetic algorithm which is optimized by the fuzzy logic controller (FLC) based on nondominated sorting genetic algorithm version II (NSGA-II) (detailed description of the fuzzy controller is given by article [39]). The modeling is done in MATLAB and Simulink to get peak response of the structure, and this result was compared with sky-ground hook algorithm and observed that the designed controller in this study performed better which involves numerical simulation only. Figure 7 represents the physical block diagram of structural control system involving all the practical devices such as controllers and dampers with feedback and feed forward loop [37].

To overcome the limitation of passive control, active control, and semi-active control, a hybrid control system is adopted by the researchers to increase the efficiency of the protective system by mitigating the response of the structure presented in [40]. The study on the response of the building is important by increasing the damping and stiffness of the building. Inter-story drift is an important parameter that addresses structural behavior; Zhou et al. [41] stated 


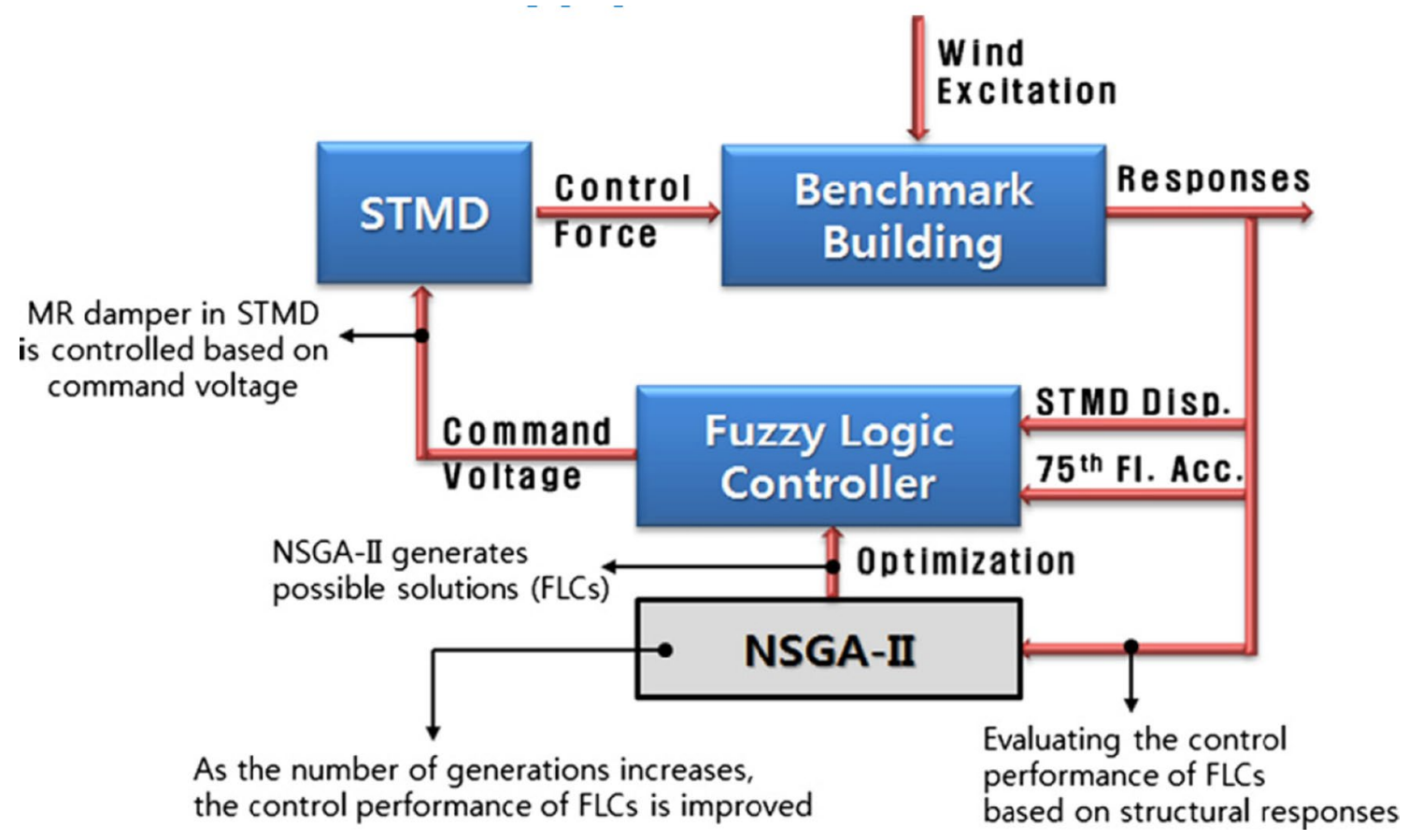

Fig. 7 Physical block diagram of structural control system [37]

harmful and harmless methods of calculation of inter-story drift. Cruz and Miranda [42] determined the damping ratio of the building considering 14 buildings in California with more than 20 stories by adopting the parametric least squares system identification technique. This method concluded with the result that as the height of the building increases, the damping ratio decreases, and steel structures have less damping ratio in comparison with concrete structures. This real-time building dynamic study prejudiced [43] to present a dynamical analysis of super tall structure Taipei 101 for earthquakes and strong typhoons; an experimental shake table test was conducted to determine the constitutive relationships between structural parameters. The time history analysis and response spectrum analysis were conducted to get lateral displacement and distributions of interior column forces, the result showed that Taipei 101 has relatively high earthquake resistance capacity and could safeguard structure during a moderate seismic event. These are some of the analyses of a tall building with different protective systems and various technical approaches to mitigate the response of the buildings without outriggers. In mitigating the response of the structure due to lateral load, outrigger structural systems are designed for better performance than the normal tall buildings without outriggers. Thus, the structure with the outrigger system is concentrate in the further section.

Analysis of outrigger in a tall building is complicated; thus, outrigger structural parameters are formulated to understand the behavior of outrigger structural systems and complicated analysis of the tall buildings can be done effortlessly. Therefore, many studies are undertaken to understand the actions of tall structures with outriggers excited for lateral load, and one of the study is presented in [44]. Alavi et al. [45] proposed the new stiffness-based method for the preliminary design of outrigger structure based on uniform distribution of deformation by keeping curvature of the beam constant. This proposed method was presented through a simplified hand calculation algorithm considering only the lateral loads and output of the novel method gave normal stress distribution uniform along with building height that was lower than permissible value [45]. Alavi et al. [45] considered only the lateral load but the vertical load was not considered in the proposed method that provides a research gap in improving the stiffness-based method for the tall building considering all the parameters in the analysis including a programing based output for preliminary and final parametric analysis. The author in paper [16] found that the equation for core rotation, restraining moment, top drift, the optimal location of outrigger to reduce the drift, and non-dimensional parameter $\Omega$ to understand the behavior of an idealized multi-outrigger structure which is the function flexural rigidity ratio was also formulated to simplify the analysis. Figure 8 shows the outrigger structural response to lateral loading and moment in the core.

The above structure is analyzed approximately by continuum approach in which the set of outriggers is smeared over the height to get closed-form solution which facilitates in producing generalized design curve as stated in the article [46]. This generalized design curve helps in producing 


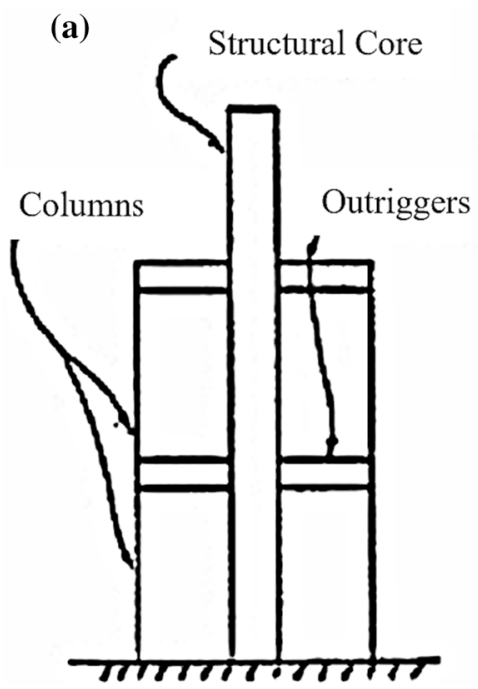

(b)

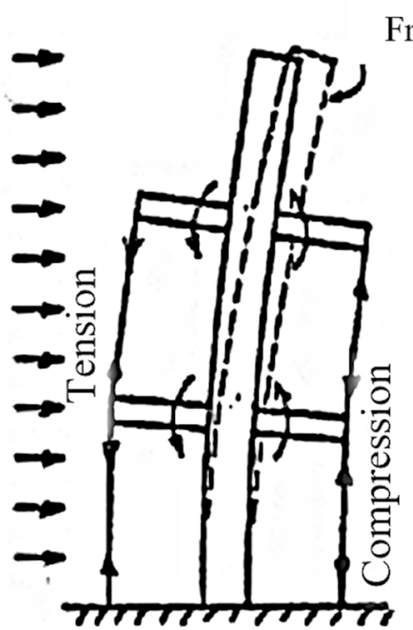

(c)

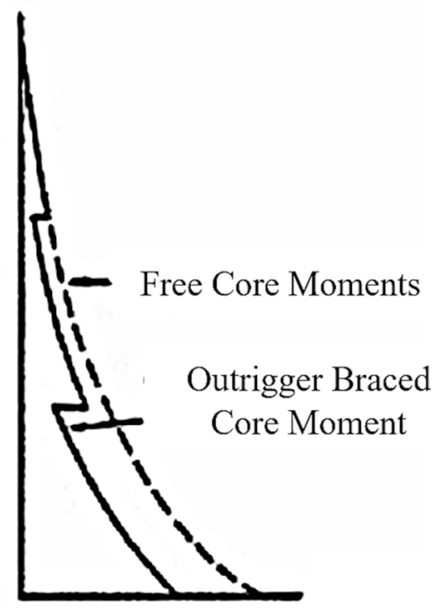

Fig. 8 a Outrigger braced structure b Response to lateral loading $\mathbf{c}$ Resultant bending moment in core [16]

a reasonably accurate result for a small or large number of the outrigger. By taking lateral load as constraining, a simple mathematical model is developed to optimally locate the outrigger and belt truss with the reduction in lateral load on the structure as presented in the article [47]. This simple mathematical model projected was applied for a numerical structure to obtain the result and was compared with the same model developed in SAP 2000 and found that the results are approximately equal and comparison is represented as when belt truss is located at $H / 6, H / 2,3 H / 4$ error in displacement at the top of the building is $1.2 \%, 2 \%, 3 \%$. A closed-loop analytical solution is a new method addressed in [48] to formulate the equation for the most advantageous location of the outrigger, damping coefficient of the damper, and the maximum damping ratio. Outrigger with the single shear wall was studied in the common but auxiliary study has been undertaken by considering a pair of the coupled shear wall by taking into account the suitability of outrigger placement at the top by $[49,50]$. This coupled shear wall is analyzed by continuous medium technique and additionally studied for its stiffness which is influenced by the type of loading, column-to-wall areas ratio, and external spans of the outrigger. After the coupled shear wall, a different approach of analyzing the outrigger is planned by authors in the article [51], by considering the outrigger as a spring and its stiffness depends on bending and racking shear in the outrigger truss and axial lengthening or shortening of the exterior columns. This approximate method of analysis relates the natural frequencies of the structure to the top deflection and rotation when the self-weight is taken as a distributed horizontal load, this method of analysis is compared with finite element analysis. An optimized analytical model is developed by Netzer and Lavan [52] using Maxwell model in connection with equation of equilibrium considering flexibility of perimeter column and outrigger excited for stochastic seismic excitations. To reduce the computational effort and number of design parameters, a novel damping distribution function is developed; consideration of flexibility in the column has shown significantly improved the performance in article [52]. There is no specific code or design guideline for the seismic response reduction by the outrigger system. But the council of tall buildings and urban habitat formed a design guide for the outrigger system with the historic overview, which provides benefits of an outrigger system, challenges for an outrigger design system, suitable condition for outrigger system, design consideration for outrigger system, organization of outrigger, and core system is illustrated in [53].

When an outrigger is introduced in a structure, it reduces the structural response but when this outrigger location is at the optimum position, the structural response is minimized to a maximum. Thus, many studies are undertaken to formulate an equation for the optimum positioning of outrigger, different approaches to find the optimum positioning, the different algorithms proposed to find the optimum positioning with reduction in the response of the structure as stated in the previous paragraph. Once the optimum position of the outrigger is found, the light weightiness of the structural system and construction cost can be calculated. Consequently, Mousleh and Batikha [54] found the optimum position of the outrigger in a structure, and then, the weight of the steel and volume of reinforced concrete are calculated according to the model without outrigger and outrigger in a different position. The authors found that an outrigger placed in optimum position gives less weight to the structural element, and therefore, the material cost decreases; hence, 
cost-effectiveness is liable for the outrigger structure. The position of the outrigger is very significant in the reduction in lateral deflection at the top of the building; thus, a graphical method is presented in [55]. The authors in this paper show a graphical method to find optimum positioning of outrigger as shown in Fig. 9 by knowing two non-dimensional characteristic parameters of structure like $\omega$ and $\gamma H$ by considering the bending stiffness and flexibility of shear wall, outrigger, and exterior column.

Most of the time graphical method does not interpret the exact result, so Zhou et al. [19] have illustrated that the program can be coded on the theoretical method to find the optimum positioning of outriggers in structure. A MATLAB program was coded by authors to analyze optimum positioning of outrigger for a $240 \mathrm{~m}$ tall 60 -floor building based on the theoretical method of inter-story drift parameter. The authors simulated single to three outrigger placement in this structure to find its optimal positioning excited for wind and earthquake loading by varying ratio of core wall area to floor area. Genetic algorithm and decision frameworks are the other solutions to find the optimum positioning of outrigger depending on some constraints, and this procedure is taken up by [56-58]. The further optimal position of the outrigger (one to four in numbers) was determined by changing the position of the outrigger in the tall building by the two constrain of reducing lateral displacement at the top level and maximum bending stress at the bottom level presented in [44]. The finite element method also can be used to locate the optimal position of the outrigger as analyzed by [59]. Optimum positioning of outrigger can be found out by analyzing an outrigger structure in different available software with response reduction has constrained by trial and error method, and many studies have been carried out as stated in the article [60].

Analysis of outrigger to study its behavior for the different configurations of the building, loading type, dampers, and bracing connections is studied using different numerical software. There are many studies undertaken using ETABS and SAP 2000 software for regular and irregular structures with a linear and nonlinear pushover analysis and time history analysis to observe the behavior under earthquake loading or wind loading as presented by [61, 62]. Amoussou et al. [63] proposed a simplified analysis method considering super-element (interval in the column and core taken as a single element) and degrees of freedom as finite element analysis. The results of the simplified analysis method were compared with the same model developed in ETABS and found that the approximate result in comparison was obtained. The study of the single and multi-outrigger system with additional features like infill wall, eccentrically bracing, conventional slab, flat slab, bare frame shear wall, connections (bolting and welding) is analyzed for the responses like displacement, base force, inter-story drift for the further enhancement of the outrigger structural system is elucidated by using the numerical software presented in $[64,65]$. The previous study explained is further varied for different loading conditions like static and dynamic loading by varying relative flexural rigidity is presented by [66]. A similar study in Midas Gen and ETABS is undertaken to find optimum outrigger geometry by the typical Maxwell-Mohr method, adopting optimal angles for three sets of height to width of a given outrigger space as stated by [67]. The study is further advanced by the addition of the viscous damper connected between the column and outrigger mainly excited for earthquake forces by $[68,69]$. The different approach of strut
Fig. 9 Optimum location of outrigger [55]

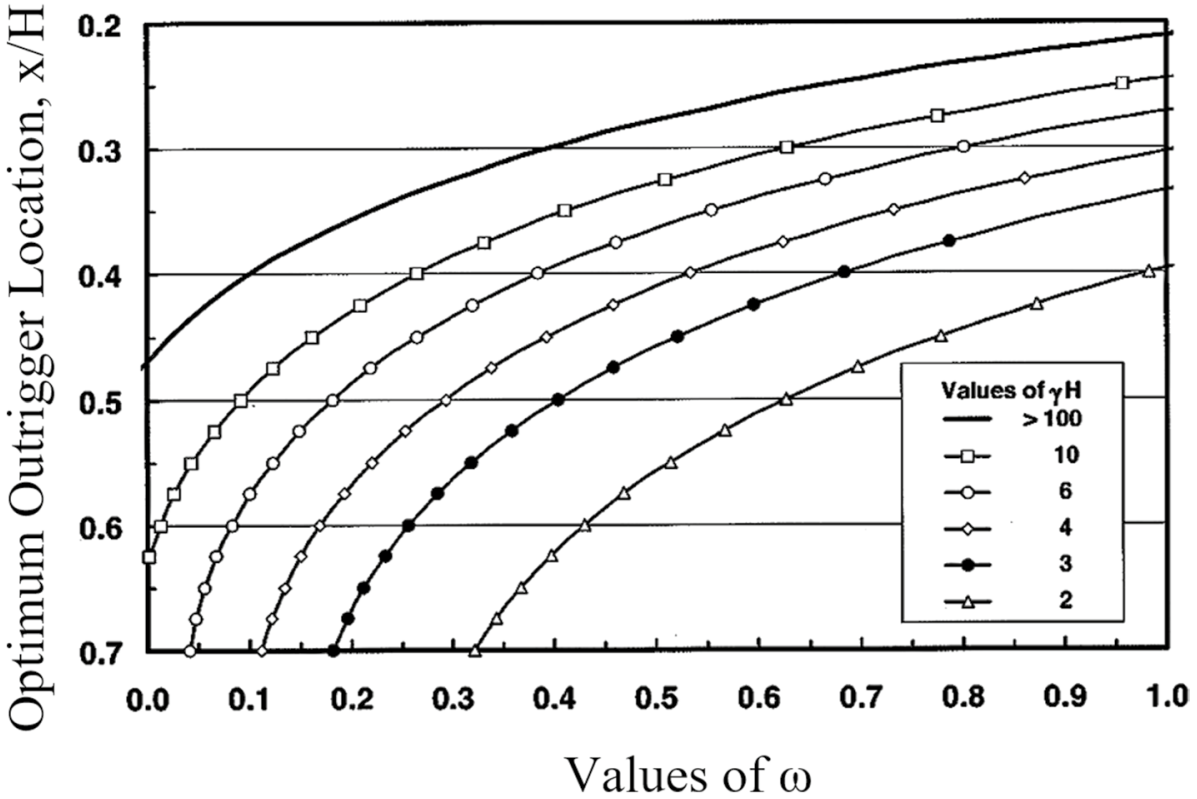


and tie method is introduced in [70] to study the general structural behavior comparing with conventional analysis of the outrigger. The outrigger trusses of various configurations were discussed and another numerical method based on finite element analysis software like ETABS and SAP 2000 was also referred to. A special type of connection called fishbone-shaped beam-column connection is modeled in [71] to represent the composite joint in a steel outrigger structure to transfer the large axial tensile forces from outrigger to concrete wall through concrete-filled steel tube column and double skinned steel plates. It is verified with a finite element model with shell and solid element, and it was found that it reasonably reflects the load distribution and enables accurate prediction of both the axial force ratio and horizontal displacement of the joint. Lu et al. [72] studied a collapse mechanism and failure mode of mega-braced frame-core tube building model based on fiber-beam and multiple layer shell model. After numerical investigation, the behavior of outriggers was tested experimentally by $[73,74]$ for retrofitted and non-retrofitted specimen that were mainly tested for their torsional strength, ductility, and energy dissipation capacity and found that after retrofitting, all the capacity increased because of plastic hinge formation in the gap. Following the literature survey done on optimum positioning of the outrigger, a few kinds of literature are shown in Table 1 for the optimum location of the outrigger in the different types and height of building excitement for a different type of loading with the structural response parameter for optimum positioning.

By finding the optimal location of the outrigger, the response of the structure can be reduced to a considerable range than an outrigger place elsewhere as shown by several literature addresses in the previous paragraphs. But this does not facilitate a decrease in the number of outriggers which will reduce the structural size and economy of the building by increasing the damping of the structure itself. When the outrigger structure is excited for lateral loads, a large amount of force induces between the outrigger and perimeter column because of redistribution of the moment. So there is a need to increase the building damping, where this limitation can be overwhelmed by using extra devices like dampers, actuators, and some other control devices. The addition of these devices in an outrigger structure between the perimeter column and end of the outrigger constitutes a structure called a damped outrigger which is an effective way to satisfy the requirement, which is explained in the further course.

Smith and Willford [77] and O'Neill [78] introduced a new concept for outrigger structural systems in tall building dynamic response and intrinsic damping called damped outrigger. The methods to mitigate the dynamic response by increasing stiffness, by the installation of tuned mass damper, viscous damper, and similar devices are illustrated with the comparison to conventional design approaches in $[79,80]$. This damped outrigger review is provided by [81],

Table 1 Optimum position of outrigger for different buildings

\begin{tabular}{|c|c|c|c|c|c|c|}
\hline Reference & $\begin{array}{l}\text { Height and no. of } \\
\text { stories in structure }\end{array}$ & Type of structure & Type of loading & \multicolumn{2}{|c|}{$\begin{array}{l}\text { Structural response param- } \\
\text { eter for optimum position }\end{array}$} & $\begin{array}{l}\text { Optimum position (single } \\
\text { outrigger) }\end{array}$ \\
\hline$[55]$ & $87 \mathrm{~m}$ (27 stories) & $\begin{array}{l}\text { Outrigger braced shear } \\
\text { wall }\end{array}$ & Wind load & \multicolumn{2}{|c|}{$\begin{array}{l}\text { Horizontal deflection and } \\
\text { displacement }\end{array}$} & $\begin{array}{l}0.33 \text { times its height from } \\
\text { the top }\end{array}$ \\
\hline$[60]$ & $187.5 \mathrm{~m}$ (50 stories) & $\begin{array}{l}\text { Outrigger with shear } \\
\text { core }\end{array}$ & Earthquake load & \multicolumn{2}{|l|}{ Story drift index } & $\begin{array}{l}0.44-0.48 \text { times its height } \\
\text { from bottom }\end{array}$ \\
\hline [19] & $240 \mathrm{~m}$ (60 stories) & $\begin{array}{l}\text { Outrigger with shear } \\
\text { core }\end{array}$ & $\begin{array}{l}\text { Wind and Earthquake } \\
\text { load }\end{array}$ & \multicolumn{2}{|l|}{ Inter-story drift } & $\begin{array}{l}0.63 \text { and } 0.67 \text { times its } \\
\text { height from the bottom }\end{array}$ \\
\hline [44] & $400 \mathrm{~m}$ (100 stories) & $\begin{array}{l}\text { Outrigger with shear } \\
\text { wall }\end{array}$ & Wind load & \multicolumn{2}{|l|}{ Top displacement } & $\begin{array}{l}0.39 \text { times its height from } \\
\text { the bottom }\end{array}$ \\
\hline [59] & $280 \mathrm{~m}$ (80 stories) & $\begin{array}{l}\text { Outrigger with shear } \\
\text { core }\end{array}$ & Wind load & \multicolumn{2}{|l|}{ Drift at top } & $\begin{array}{l}0.375 \text { times its height } \\
\text { from top }\end{array}$ \\
\hline$[75]$ & $201 \mathrm{~m}$ (67 stories) & $\begin{array}{l}\text { Outrigger and belt truss } \\
\text { with shear core }\end{array}$ & Wind load & \multicolumn{2}{|l|}{ Top displacement } & $\begin{array}{l}0.31 \text { times its height from } \\
\text { the bottom }\end{array}$ \\
\hline \multirow[t]{4}{*}[76]{} & a) $70 \mathrm{~m}$ (20 stories) & \multirow[t]{4}{*}{$\begin{array}{l}\text { Outrigger with shear } \\
\text { wall with belt truss }\end{array}$} & Earthquake load & a) & $\begin{array}{l}\text { Drift } \\
\text { Weight }\end{array}$ & $\begin{array}{l}\text { More than one outrigger } \\
6,12,16 \text { floor } \\
12 \text { floor }\end{array}$ \\
\hline & b) $105 \mathrm{~m}$ (30 stories) & & & b) & $\begin{array}{l}\text { Drift } \\
\text { Weight }\end{array}$ & $\begin{array}{l}6,12,18,24 \text { floor } \\
8,15,24 \text { floor }\end{array}$ \\
\hline & c) $140 \mathrm{~m}$ (40 stories) & & & c) & $\begin{array}{l}\text { Drift } \\
\text { Weight }\end{array}$ & $\begin{array}{l}12,20,26,34 \text { floor } \\
12,20,32 \text { floor }\end{array}$ \\
\hline & d) $175 \mathrm{~m}$ (50 stories) & & & d) & $\begin{array}{l}\text { Drift } \\
\text { Weight }\end{array}$ & $\begin{array}{l}12,26,34,42 \text { floor } \\
12,18,30,42 \text { floor }\end{array}$ \\
\hline
\end{tabular}


he stated the mechanism of damped outrigger where the dampers are installed between the outrigger end and perimeter column, calculation methods for damping, the external force effect on the outrigger structure, the methods to optimize damping system, an example of three building which uses damped outrigger system is elaborated. In damped outrigger systems, the column performance is neglected in dynamics of the structural equation of motion and the performance is observed, building damping calculation is done and also practical design consideration with design example is presented in [82]. Figure 10 shows the mechanism of the damped outrigger concept which considers the involvement of the column dynamic condition in the outrigger structural equation of motion stated by the article [83].

Variables in Fig. 10 represent material properties and structural dimensions. $E$ represents Young's modulus, $I-$ moment of inertia, $\rho$-density of the material used for the structure, $h$ - total height of the building, $e$-span of outrigger, $\alpha$ is the ratio of total height of the core where outrigger is placed, $A$ is the area of the core, and $f$-force produced by the damper.

A new approach of structural dynamics of the damped outriggers is studied by compatibility equations and boundary conditions; but article [84] adapted dynamic stiffness method to formulate the governing equation for three-parameter such as damper coefficient installed stiffness ratio of core to the column and location of the damped outrigger. The authors found that the damping ratio of the structure is significantly persuaded by the stiffness ratio of the core and column. The passive protective system like a TMD, TLD, the viscous damper is used to reduce the response as passive dampers in damped outriggers as

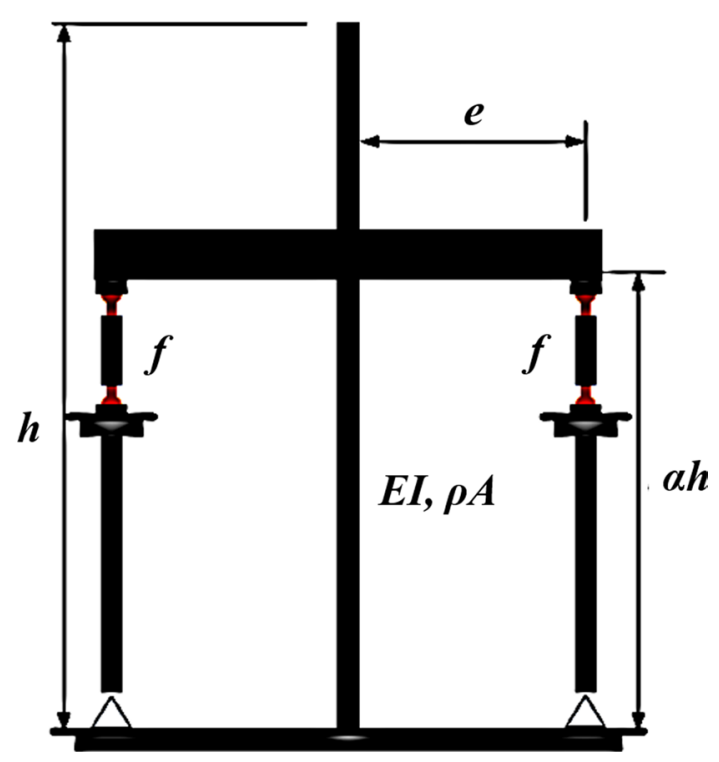

Fig. 10 Mechanism of outrigger system [83] stated in [85]. To study viscous damper, article [86] presented performance variation in the real-time tall buildings installed in it for wind and earthquake forces. The authors illustrated the examples of the twin St. Francis ShangriLa Towers in Manila, Philippines, and the Taipei 101 in Taipei, Taiwan, which is considered to explain the technology involved and wide laboratory testing campaign aimed at verifying their behavior during both wind and earthquake. Taipei 101 is a practical example of a skyscraper that uses TMD that is spherical with mass of 660 metric tons suspended with cables as a single-stage pendulum with primary viscous damper connected in resisting acceleration of the structure induced by the wind as a state by the article [87]. Figure 11 shows general configuration of TMD and viscous damper integrated with TMD.

To improve the performance of the viscous damped outrigger, Wand et al. [88] introduced a negative stiffness device using a pre-compressed spring and a pivot lever is installed along with the viscous damper between the perimeter column and outrigger as shown in Fig. 12. A parametric study is conducted introducing negative stiffness in transcendental characteristic equations of the structure to get improved damping capacity and reduce the structural responses as in the article [89].

After the real structural application observation of tall buildings, there are some shortcomings for every tall structural form and the outrigger structural system limitations like differential shortening, the disproportionate collapse of structure with outrigger, toppling of building structures; all these issues are addressed by $[90,91]$. To overcome the limitation of a TMD of supplemental mass, article [92] introduced tuned viscous mass damper for outrigger structure excited for particularly earthquake rather than wind load. In tuned viscous mass damper, apparent mass is realized by an inertial mass through a ball screw mechanism which acts better than a TMD. Luo et al. [93] studied dynamic cyclic tests and numerical analysis of amplified viscous damped outrigger (AVDO) achieved by adding steel devices to improve the performance of the passively working damper. In Fig. 13, a viscous damper connected to the outrigger truss and the column is shown as viscous damped outrigger (VDO); this VDO connection is then modified with the addition of toggle-brace and lever arm to produce togglebraced viscously damped outrigger (TBVDO) and leverarmed viscously damped outrigger (LAVDO) to enhance the performance of the structural response. $\theta_{1}, \theta_{2}, \theta_{3}$ are the arrangement angles of brace in TBVDO, and $l_{\mathrm{h}}, l_{\mathrm{v}}$ are the horizontal and vertical length of the lever arm amplifying device. A study on AVDO concludes that there is greater dissipation of input seismic force and hysteresis curve of LAVDO is symmetric and full in comparison with TBVDO. So authors have concluded that LAVDO is more suitable for engineering applications. 


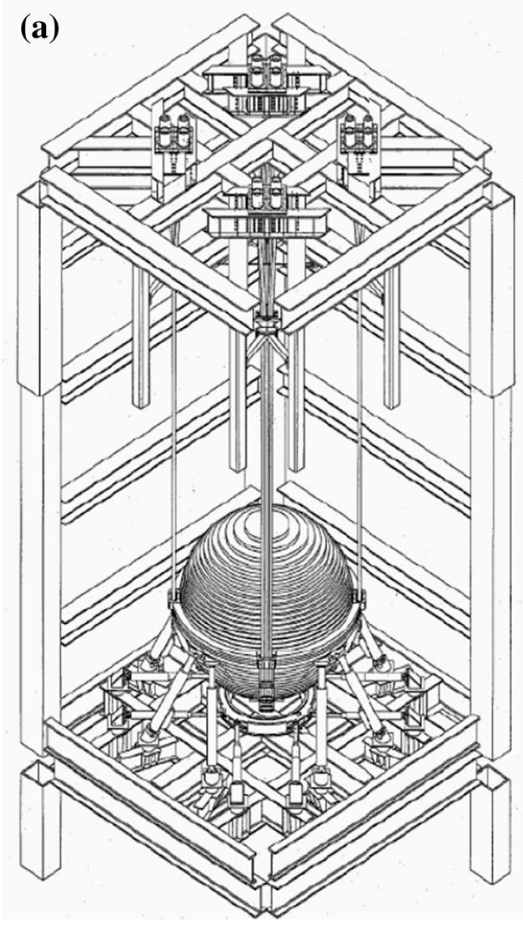

(b)

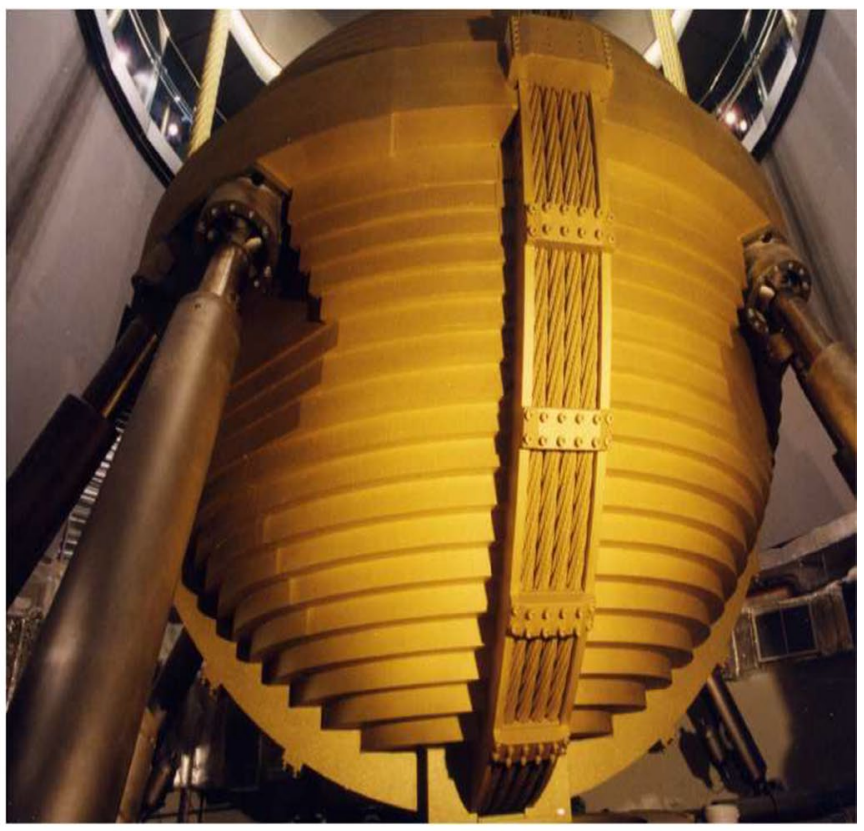

Fig. 11 a General configuration of TMD b) Viscous damper integrated with TMD

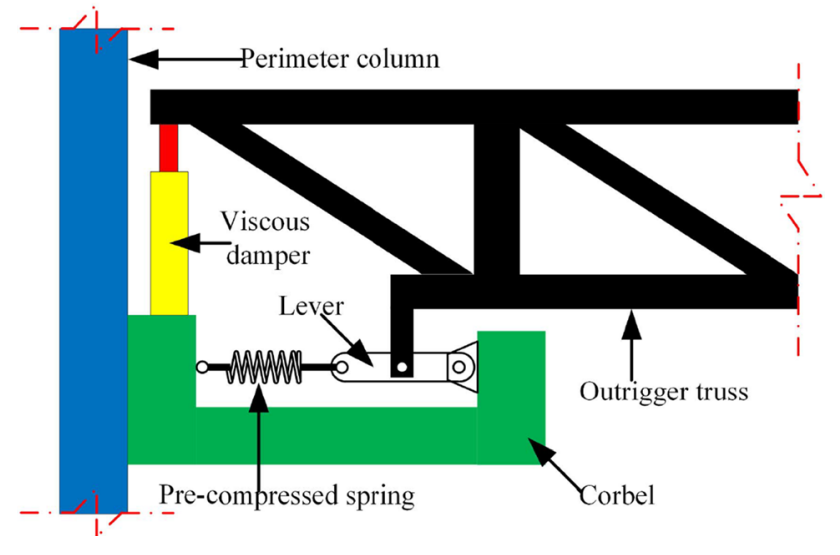

Fig. 12 Mechanism of outrigger system [88]

As observed in earlier paragraphs, the passive dampers are not very prominent in structural control, thus the article [21] studied damped outriggers with a combination of a protective system like passive dampers and active dampers to produce hybrid damping and comprehend the outrigger behavior. The author found that the hybrid damped outrigger reduces the displacement up to $20-30 \%$ in comparison with the passively damped outrigger. Another semi-active damper which has proved to be a promising device in structural control is magneto-rheological fluid damper, which has a wide application in all the control system including building used as semi-active damper as stated by $[94,95]$ and as elastomer for base isolation as elucidated by articles [96, 97]. Considerably, Wang et al. [98] presented a study on semi-active control strategy employed in St. Francis Shangri-La Palace in Manila, Philippines, by using a MR damper with clipped optimal control algorithm combined with linear quadratic Gaussian acceleration feedback control algorithm. The clipped optimal control algorithm is compared with viscous damper placement in place of MR damper, which showed better performance than viscous damper in the response control of the outrigger structure. This study was further evaluated for the damper size and location by the article [83]. St. Francis Shangri-La Palace in the Philippines is further studied for tuned inertial mass electromagnetic transducer as a damper, and the performance of the structure was observed by the article [99]. This intended damper by authors is compared with electromagnetic transducers and found that the designed damper system is effective in vibration reduction for time history analysis. As MR damper has proved to be a promising device in structural control, in the article [100], a fuzzy logic algorithm is combined with genetic algorithm optimization for reducing the outrigger structural response. From this study, the displacement of the structure excited for an earthquake is shown in Fig. 14.

A novel energy dissipation system is designed by Tan et al. [101] considering the interaction between perimeter columns and the dampers in damped outriggers. By this designed method outrigger location, stiffness ratio of core to the outrigger, damping coefficient of the damper were 


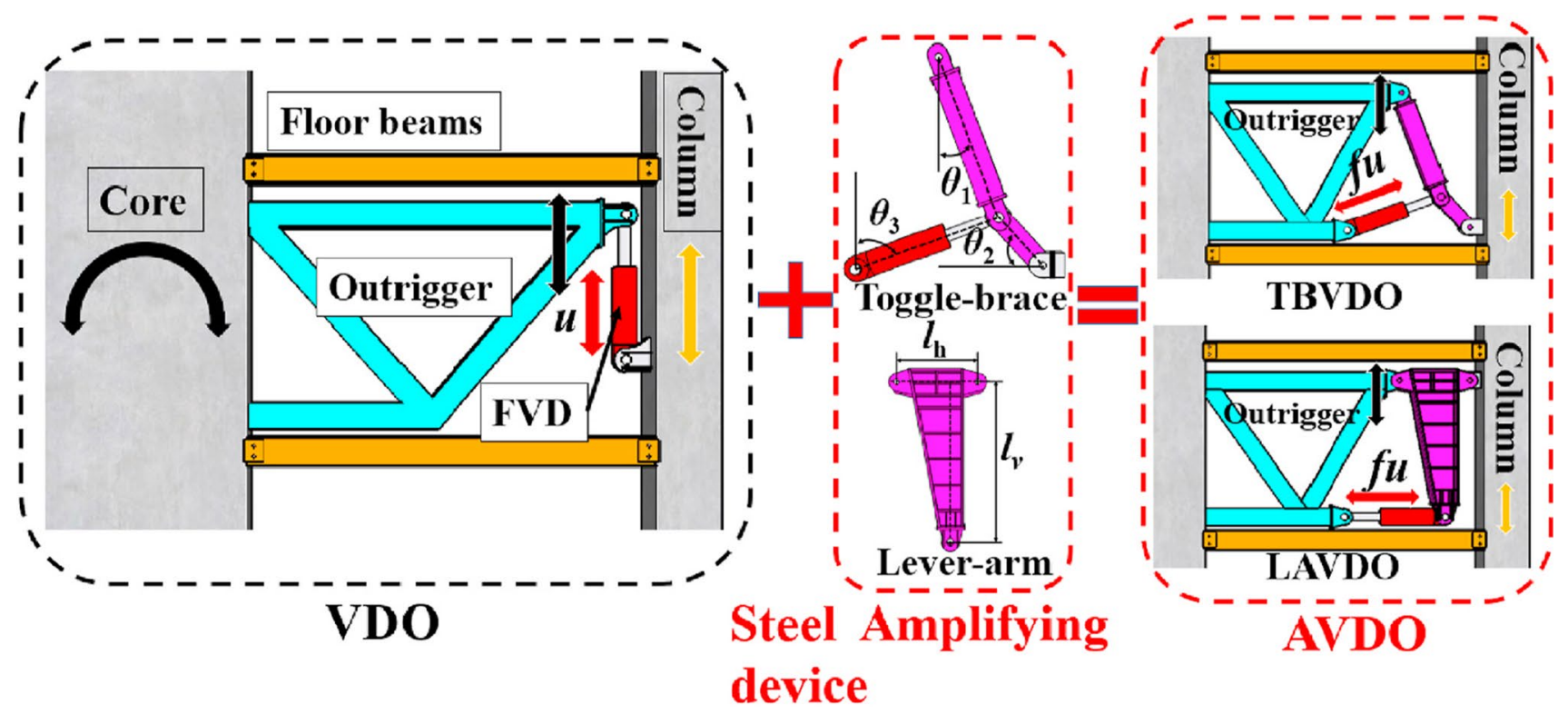

Fig. 13 Integrated steel amplification devices with viscous damper [93]

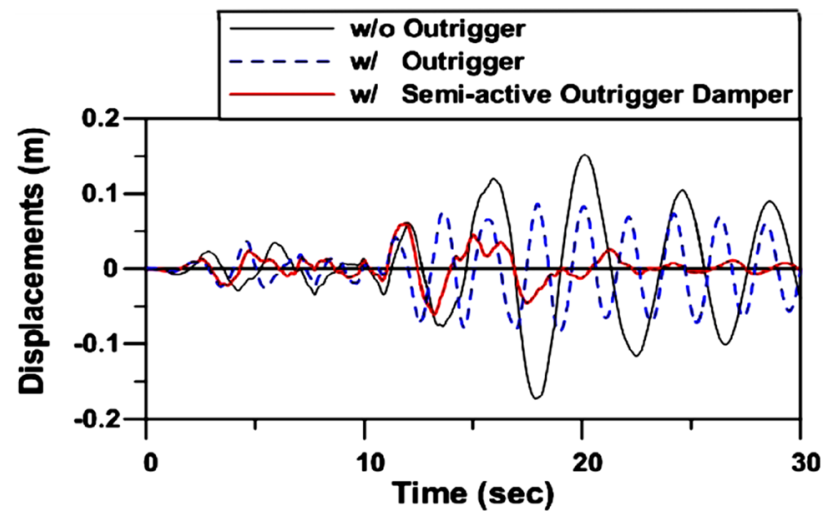

Fig. 14 Displacement of structure without and with outrigger and semi-active outrigger [100]

found, and this model is evaluated by comparing it with the finite element model. Lin et al. [102, 103] presented buckling restrained brace in place of the damper in between the perimeter column and outrigger end for single and multiple outriggers and formulated the dynamics of the structure with buckling restrained brace, shear wall, perimeter column, and outrigger to mitigate the response of the structure. Zhou et al. [104] developed a combined damped outrigger system with the viscous damper in a combination of the buckling restrained braces with the novel frequency-based analysis. A simplified model developed in the time domain is then converted to the frequency domain to find the amplitude, phase, and variance. The combined damped outrigger system shows a better energy dissipation, and in practical situations, the buckling restrained braces outrigger placement above viscously damped outrigger is recommended for better performance [104]. Another numerical method was executed in the article [105], which applied the separation of the variable method to convert the partial differential equation of motion to an ordinary differential equation. The authors used three numerical examples with different stepped discontinuities in their cross sections that are been studied to demonstrate the reliability of this method. The theoretical study presented earlier has no experimental validation; hence, to validate this theory, a real-time hybrid simulation (RTHS) is taken up in which damping devices are tested experimental, whereas remaining structural models are numerically simulated as presented by articles [106-109] and presented a study which adopted St. Francis Shangri-La Palace in the Philippines for RTHS with experimental setup MR damper driven by a hydraulic actuator, where the numerical model of the structure was simulated in MATLAB and Simulink as shown in Fig. 15, where $f_{\mathrm{MR}}$ is the MR damper force measured by the load cell, $x$ is the displacement measured by the linear variable displacement transducer, and $i$ is the control current sent to the hydraulic actuator as stated by the article [110].

The damped outrigger analysis is done by a stochastic optimization procedure by Fang et al. [111], where the earthquake is modeled as filtered white noise following the Kanai-Tajimi spectrum. The author modeled the core the structure using Timoshenko beam, a Kelvin model of the damper, and the genetic algorithm was used to determine the damper placement and associated parameters to minimize structural responses. There is a need to improve the performance of damped outriggers by using the hybrid 


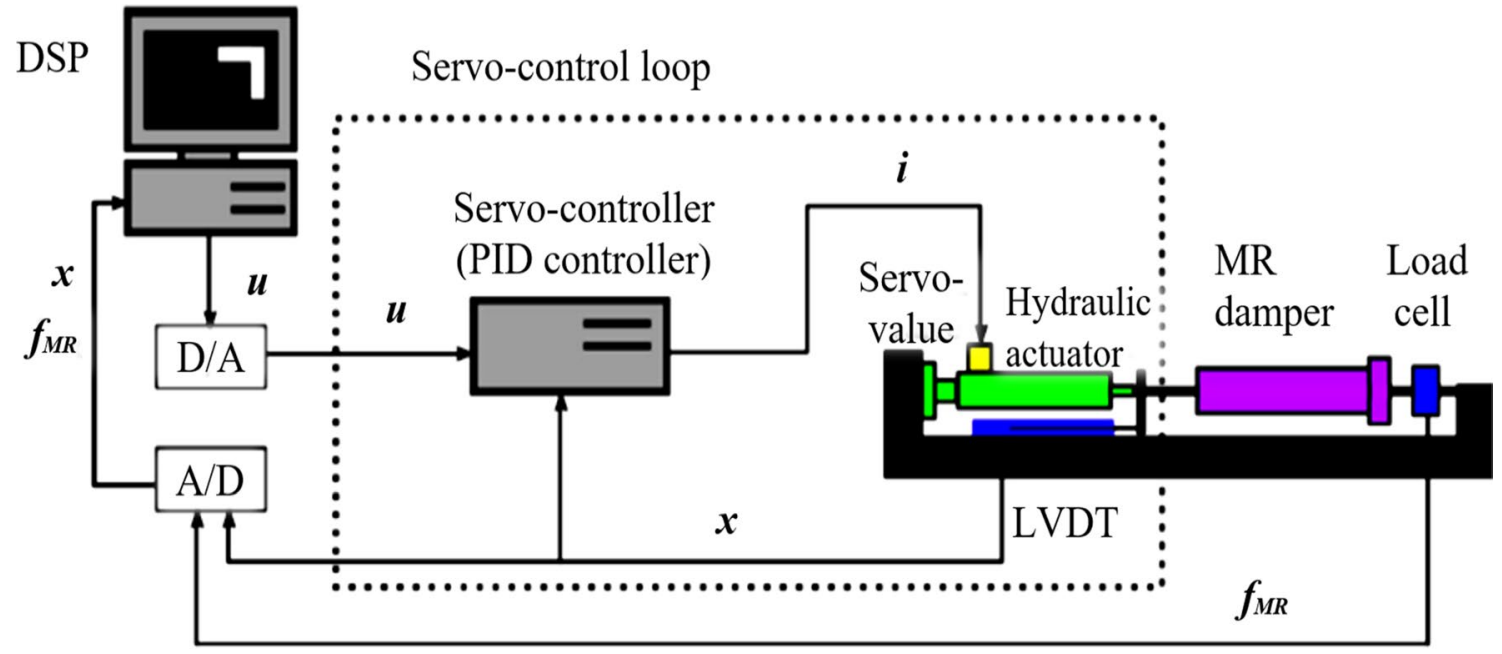

Fig. 15 Schematic diagram of real-time hybrid simulation [110]

damping system and semi-active dampers regulated by different control algorithms to enhance the outrigger structural behavior.

\section{Conclusion}

This review paper introduces a concept of outrigger which was historically started as use in canoes, then gradually usage extended to the tall building and skyscrapers in mitigating the structural response and to add stability. The literature survey done on the outrigger structural proves its significance in the tall building response control and shows it is efficient in high-rise buildings as a lateral load resistant technique by mitigating the vibration response of the building. An optimum outrigger structure is being developed to make this technology economic and many studies are done, respectively. The introduction of novelist concepts of damped outrigger has accounted for more advantage by reducing the vibration of the building with the addition of reduction in lateral design forces. Because of the reduction in lateral design forces, there is an increase in structural damping, which has also led to the reduction in structural member size and construction cost. Although damped outrigger with a controller is still an upcoming design and relatively new methodology in structural control and monitoring, it has enormous untapped potential in the structural design and construction sector. Based on the state-of-the-art review, it can be summarized that there is a need for a more precise semi-active and hybrid control techniques to make the outrigger structural system perform better and more economically feasible.

\section{Future Scope}

This paper discusses the evolution of the outrigger from the history of its usage in canoes to the new concept of the damped outrigger with novel control system concepts. This review paper paves the way for real-time hybrid simulation of the novel control system with the novel dampers which are recently developed with the adoption of simplified preliminary design concepts. There is a new area of research in the damped outrigger structural control by incorporating adaptive control, robust control, and stochastic control. The outrigger structural system can also be studied for the stochastic optimal control which resembles the randomness in the structural control. So randomness can be considered in structural dynamical properties, feedback control randomness, lateral load excitation distributed through the appropriate filter, randomness in actuator dynamical behavior, and randomness in the design of outrigger including the topology, energy dissipation, differential shorting, the construction pattern, etc. As the construction sector is a complex data management system, the big data technology can be incorporated in processing, storage, and databases in the enhancement of the structural response mitigation. As vibration control of the structural system is upcoming technology and is a new innovative area in research, this has a huge potential in construction industries.

Acknowledgements We would like to thank the Manipal Academy of Higher Education, Manipal, Karnataka, for providing all the required facilities. We would also like to thank all the referees cited in this paper. 
Funding Open access funding provided by Manipal Academy of Higher Education, Manipal.

Open Access This article is licensed under a Creative Commons Attribution 4.0 International License, which permits use, sharing, adaptation, distribution and reproduction in any medium or format, as long as you give appropriate credit to the original author(s) and the source, provide a link to the Creative Commons licence, and indicate if changes were made. The images or other third party material in this article are included in the article's Creative Commons licence, unless indicated otherwise in a credit line to the material. If material is not included in the article's Creative Commons licence and your intended use is not permitted by statutory regulation or exceeds the permitted use, you will need to obtain permission directly from the copyright holder. To view a copy of this licence, visit http://creativecommons.org/licenses/by/4.0/.

\section{References}

1. Smith, R.J.: Deflection limits in tall buildings - are they useful?. In: Structures Congress, Las Vegas, Nevada, United States (2011). https://doi.org/10.1061/41171(401)45

2. Rahgozar, P.: Free vibration of tall buildings using energy method and hamilton's principle. Civ. Eng. J. 6(5), 945-953 (2020). https://doi.org/10.28991/cej-2020-03091519

3. Ali, M.M.; Moon, K.S.: Structural developments in tall buildings: Current trends and future prospects. Archit. Sci. Rev. 50(3), 205-223 (2007). https://doi.org/10.3763/asre.2007.5027

4. Moon, K.S.; Ali, M.M.: Advances in structural systems for tall buildings: emerging developments for contemporary urban giants. Buildings 8(104), 1-34 (2018)

5. Choi, H.; Ho, G.; Joseph, L.; Mathias, N.: Outrigger design for high rise buildings: an output of the CTBUH outrigger working group. Council on Tall Buildings and Urban Habitat, Chicago (2012)

6. Baker, W.F.; Korista, D.S.; Novak, L.C.: Engineering the world's tallest - Burj Dubai. In: CTBUH 8th World Congress, Dubai (2008). https://doi.org/10.1002/tal.418

7. Safarik, D.: Tall buildings in numbers. Int. J. Tall Build. Urban Habitat CTBUH J. 1, 48-49 (2019)

8. Sharma, A.; Mittal, H.; Gairola, A.: Mitigation of wind load on tall buildings through aerodynamic modifications: Review. J. Build. Eng. 18, 180-194 (2018). https://doi.org/10.1016/j.jobe. 2018.03.005

9. Alhaddad, W.; Halabi, Y.; Xu, H.; Lei, H.G.: A comprehensive introduction to outrigger and belt-truss system in skyscrapers. Structures 27, 989-998 (2020). https://doi.org/10.1016/j.istruc. 2020.06.028

10. Anvar, N.; Aung, T.H.; Najam, F.: Smart systems for smart structures. Technology 33-39 (2016)

11. Alavi, A.; Dolatabadi, M.; Mashhadi, J.; Noroozinejad, F.E.: Simultaneous optimization approach for combined controlstructural design versus the conventional sequential optimization method. Struct. Multidiscip. Optim. 63(3), 1367-1383 (2021). https://doi.org/10.1007/s00158-020-02765-3

12. Wang, Z.; Pan, W.; Zhang, Y.: Parametric study on module wall-core system of concrete modular high-rises considering the influence of vertical inter-module connections. Eng. Struct. 241, 112436 (2021). https://doi.org/10.1016/j.engstruct.2021.112436

13. Zhang, L.; Du, W.; Zhu, B.: Quasi-static testing and numerical simulation study on seismic performance of reinforced concrete core wall with embedded steel frame under sequentially bidirectional loading. Soil Dyn. Earthq. Eng. 148, 106847 (2021). https://doi.org/10.1016/j.soildyn.2021.106847
14. Ho, G.W.M.: The evolution of outrigger system in tall buildings. Int. J. High-Rise Build. 5(1), 21-30 (2016). https://doi.org/10. 21022/ijhrb.2016.5.1.21

15. Abramovitch, D.: The outrigger: a prehistoric feedback mechanism. IEEE Control Syst. 2(4), 57-72 (2005). https://doi.org/10. 1109/MCS.2005.1499391

16. Smith, B.S.; Salim, I.: Parameter study of outrigger-braced tall building structures. J. Struct. Div. 107(10), 2010-2014 (1981)

17. Mousleh, I.: Optimum usage of outriggers in steel tall buildings. Dissertation, Heriot Watt University, Dubai (2017). https://doi. org/10.13140/RG.2.2.17975.37287

18. Zhou, Y.; Zhang, C.; Lu, X.: Seismic performance of a damping outrigger system for tall buildings. Struct. Control Health Monit. 24(1), 1-16 (2016). https://doi.org/10.1002/stc.1864

19. Zhou, Y.; Zhang, C.; Lu, X.: An inter-story drift -based parameter analysis of optimal location of outrigger in tall buildings. Struct. Design Tall Spec. Build. 25(5), 215-231 (2015). https:// doi.org/10.1002/tal.1236

20. Taranath, B.S.: Wind and Earthquake Resistant Buildings. Marcel Dekker, Cimarron Road, Monticello, New York (2005)

21. Feng, J.: Hybrid damping system for high-rise building outriggers. Dissertation, Massachusetts Institute of Technology, USA (2014)

22. Lame, A.: Optimization of outrigger structures. Dissertation, Massachusetts Institute of Technology, USA (2008)

23. Smith, S.B.; Coull, A.: Tall Building Structures: Analysis and Design. Wiley, New York, USA (1991)

24. Eom, T.S.; Murmu, H.; Yi, W.: Behavior and design of distributed belt walls as virtual outriggers for concrete high-rise buildings. Int. J. Concr. Struct. Mater. 13(1), 1-13 (2019). https://doi. org/10.1186/s40069-018-0311-2

25. Kareem, A.; Kijewski, T.; Tamura, Y.: Mitigation of motions of tall buildings with specific examples of recent applications. Wind Struct. 2(3), 201-251 (1999). https://doi.org/10.12989/was. 1999.2.3.201

26. Gunel, M.H.; Ilgin, H.E.: A proposal for the classification of structural systems of tall buildings. Build. Environ. 42, 26672675 (2007). https://doi.org/10.1016/j.buildenv.2006.07.007

27. Alhaddad, W.; Halabi, Y.; Xu, H.; Lei, H.: Outrigger and belttruss system design for high-rise buildings: a comprehensive review part ii - guideline for optimum topology and size design. Adv. Civ. Eng. (2020). https://doi.org/10.1155/2020/2589735

28. Soong, T.T.; Spencer, B.F.: Supplemental energy dissipation: State-of-the-art and state-of-the practice. Eng. Struct. 24, 243 259 (2002). https://doi.org/10.1016/S0141-0296(01)00092-X

29. Housner, G.W.; Bergman, L.A.; Caughey, T.K.; Chassiakos, A.G.; Claus, R.O.; Masri, S.F.; Skelton, R.E.; Soong, T.T.; Spencer, B.F., Jr.; Yao, J.T.P.: Structural control: past, present and future. J. Eng. Mech. 123, 897-971 (1997). https://doi.org/10. 1061/(ASCE)0733-9399(1997)123:9(897)

30. Spencer, B.F.; Nagarajaiah, S.: State of the art of structural control. J. Struct. Eng. 129, 845-865 (2003)

31. Kameshki, E.S.; Saka, M.P.: Genetic algorithm based optimum bracing design of non-swaying tall plane frames. J. Constr. Steel Res. 57, 1081-1097 (2001). https://doi.org/10.1016/S0143974X(01)00017-7

32. Spence, S.M.J.; Kareem, A.: Tall buildings and damping: a concept-based data-driven model. J. Struct. Eng. 140(5), 1-15 (2014). https://doi.org/10.1061/(ASCE)ST.1943-541X.0000890

33. Bhosale, A.D.; Murudi, M.M.: Seismic control of structures using sloped bottom tuned liquid dampers. Struct. Eng. Mech. 64(2), 233-241 (2017). https://doi.org/10.12989/sem.2017.64.2. 233

34. Mohite, A.A.; Patil, G.R.: Earthquake analysis of tall building with tuned mass damper. IOSR J. Mech. Civ. Eng. pp. 113-122 (2015) 
35. Giaralis, A.; Petrini, F.: Wind induced vibration mitigation in tall buildings using the tuned mass damper inerter. J. Struct. Eng. 143(9), 1-11 (2016). https://doi.org/10.1061/(ASCE)ST.1943541X.0001863

36. Chandiramani, N.K.: Semi active control of earthquake/wind excited buildings using output feedback. Procedia Eng. 144, 1294-1306 (2015). https://doi.org/10.1016/j.proeng.2016.05.127

37. Kim, H.S.; Kang, J.W.: Semi-active fuzzy control of a windexcited tall building using multi-objective genetic algorithm. Eng. Struct. 41, 242-257 (2012). https://doi.org/10.1016/j.engst ruct.2012.03.038

38. Yang, J.N.; Agrawal, A.K.; Samali, B.; Wu, J.C.: Benchmark problem for response control of wind-excited tall buildings. J. Eng. Mech. 130(4), 437-446 (2004). https://doi.org/10.1061/ (ASCE)0733-9399(2004)130:4(437)

39. Bozorgvar, M.; Zahrai, S.M.: Semi-active seismic control of a 9-story benchmark building using adaptive neural-fuzzy inference system and fuzzy cooperative coevolution. Smart Struct. Syst. 23(1), 1-14 (2019). https://doi.org/10.12989/sss.2019. 23.1.001

40. Aly, A.M.: Control of wind-induced motion in high-rise buildings with hybrid TM/MR dampers. Wind Struct. 21(5), 565$595(2015)$

41. Zhou, J.; Bu, G.B.; Li, K.N.: Calculation methods for interstory drifts of building structures. In: 15th World Conference on Earthquake Engineering, Lisbon, Portugal (2012). https:// doi.org/10.1260/1369-4332.17.5.735

42. Cruz, C.; Miranda, E.: Evaluation of damping ratios for the seismic analysis of tall buildings. J. Struct. Eng. 143(1), 1-10 (2016). https://doi.org/10.1061/(ASCE)ST.1943-541X.00016 28

43. Fan, H.; Li, Q.S.; Tuan, A.Y.; Xu, L.: Seismic analysis of the world's tallest building. J. Constr. Steel Res. 65, 1206-1215 (2009). https://doi.org/10.1016/j.jcsr.2008.10.005

44. Taranath, B.S.: Structural Analysis and Design of Tall Buildings. Taylor \& Francis Group, Boca Raton (2012)

45. Alavi, A.; Mele, E.; Rahgozar, R.; Noroozinejad Farsangi, E.; Takewaki, I.; Málaga-Chuquitaype, C.: Uniform deformation design of outrigger braced skyscrapers: a simplified method for the preliminary design stage. Structures 31, 395-405 (2021). https://doi.org/10.1016/j.istruc.2021.01.099

46. Coull, A.; Lau, W.H.O.: Analysis of multi-outrigger-braced structures. J. Struct. Eng. 115(7), 1811-1855 (1989). https://doi.org/ 10.1061/(ASCE)0733-9445(1989)115:7(1811)

47. Rahgozar, R.; Ahmadi, A.R.; Sharifi, Y.: A simple mathematical model for approximate analysis of tall buildings. Appl. Math. Model. 34, 2437-2451 (2010). https://doi.org/10.1016/j.apm. 2009.11.009

48. Chen, Y.; McFarland, D.M.; Wang, Z.; Spencer, B.F.; Bergman, L.A.: Analysis of tall buildings with damped outriggers. J. Struct. Eng. 136(11), 1435-1443 (2010). https://doi.org/10.1061/ (ASCE)ST.1943-541X.0000247

49. Moudarres, F.R.: Outrigger-braced coupled shear walls. J. Struct. Eng. 110(12), 2876-2890 (1984). https://doi.org/10.1061/ (ASCE)0733-9445(1984)110:12(2876)

50. Zeidabadi, N.A.; Mirtalae, K.; Mobasher, B.: Optimized use of the outrigger system to stiffen the coupled shear walls in tall buildings. Struct. Design Tall Spec. Build. 13, 9-27 (2004). https://doi.org/10.1002/tal.228

51. Nicoreac, M.; Hoenderkamp, J.C.D.: Periods of vibration of braced frames with outriggers. Procedia Eng. 40, 298-303 (2012). https://doi.org/10.1016/j.proeng.2012.07.098

52. Netzer, I.; Lavan, O.: Optimized seismic design of passively damped outriggers considering perimeter column flexibility. J. Struct. Eng. 146(12), 04020254 (2020). https://doi.org/10.1061/ (asce)st.1943-541x.0002825
53. Choi, H.S.; Joseph, L.: Outrigger system design considerations. Int. J. High. Rise Build. 1(3), 234-246 (2012)

54. Mousleh, I.; Batikha, M.: The cost efficiency by using outriggers in tall buildings. In: Proceedings of 9th International Conference on Contemporary Issues in Science. Engineering \& Management, Dubai, UAE (2018)

55. Hoendarkamp, J.D.C.; Bakker, M.C.M.; Snijder, H.H.: Preliminary design of high rise outrigger braced shear wall structures on flexible foundations. HERON 48(2), 81-98 (2003)

56. Park, H.S.; Lee, E.; Choi, S.W.; Oh, B.K.; Cho, T.; Kim, Y.: Genetic- algorithm-based minimum weight design of an outrigger system for high rise buildings. Eng. Struct. 117, 496-505 (2016). https://doi.org/10.1016/j.engstruct.2016.02.027

57. Chen, Y.; Zhang, Z.: Analysis of outrigger numbers and locations in outrigger braced structures using multi objective genetic algorithm. Struct. Des. Tall Spec. Build. 27(1), 1-16 (2018). https:// doi.org/10.1002/tal.1408

58. Zhou, K.; Luo, X.W.; Li, Q.S.: Decision framework for optimal installation of outrigger in tall buildings. Autom. Constr. 93, 200-213 (2018). https://doi.org/10.1016/j.autcon.2018.05.017

59. Kim, H.: Optimum design of outriggers in a tall building by alternative non-linear programming. Eng. Struct. 150, 91-97 (2017). https://doi.org/10.1016/j.engstruct.2017.07.043

60. Herath, N.; Haritos, N.; Ngo, T.; Mendis, P.: Behaviour of outrigger beams in high rise buildings under earthquake loads. In: Australian Earthquake Engineering Society 2009 Conference, Newcastle, Australia (2009)

61. Kian, P.S.; Siahaan, F.T.: The use of outrigger and belt truss system for high-rise concrete buildings. Dimensi Tek. Sipil 3(1), 1410-9530 (2001)

62. Balling, R.J.; Lee, J.S.: Simplified model for analysis and optimization of skyscrapers with outrigger and belt trusses. J. Struct. Eng. 141(9), 1-9 (2015). https://doi.org/10.1061/ (ASCE)ST.1943-541X.0001210

63. Amoussou, C.P.D.; Lei, H.; Alhaddad, W.; Halabi, Y.: Simplified modeling and analysis method for skyscrapers with outrigger system. Structures 33, 1033-1050 (2021). https://doi.org/ 10.1016/j.istruc.2021.04.096

64. Brunesi, E.; Nascimbene, R.; Casagrande, L.: Seismic analysis of high-rise mega-braced frame-core buildings. Eng. Struct. 115, 1-17 (2016). https://doi.org/10.1016/j.engstruct.2016.02. 019

65. Patil, D.M.; Sangle, K.K.: Seismic behaviour of outrigger braced systems in high rise 2-D steel buildings. Structures 8, 1-16 (2016). https://doi.org/10.1016/j.istruc.2016.07.005

66. Kamath, K.; Divya, N.; Rao, A.U.: A study on static and dynamic behavior of outrigger structural system for tall buildings. Bonfring Int. J. Ind. Eng. Manag. Sci. 2(4), 15-20 (2012). https://doi. org/10.9756/BIJIEMS.1655

67. Lee, D.; Shin, S.; Doan, Q.H.: Real-time robust assessment of angles and positions of non-scaled steel outrigger structure with Maxwell-Mohr method. Constr. build. Mater. 186, 1161-1176 (2018). https://doi.org/10.1016/j.conbuildmat.2018.07.212

68. Zhou, Y.; Li, H.: Analysis of a high-rise steel structure with viscous damped outriggers. Struct. Des. Tall Spec. Build. 23, 963-979 (2014). https://doi.org/10.1002/tal.1098

69. Ding, J.; Wang, S.; Wu, H.: Seismic performance analysis of viscous damping outrigger in super high-rise buildings. Struct. Des. Tall Spec. Build. 27, 1-22 (2018). https://doi.org/10.1002/ tal. 1486

70. Su, R.K.L.; Wong, P.C.W.; Chandler, A.M.: Application of strutand-tie method on outrigger braced core wall buildings. In: Tall Buildings from Engineering to Sustainability - Sixth International Conference on Tall Buildings, China, pp. 80-85 (2005). https://doi.org/10.1142/9789812701480_0013 
71. Ding, R.; Nie, X.; Tao, M.X.; Fan, J.S.: Fishbone-shaped beamcolumn model for steel outrigger truss-concrete wall composite joints. J. Constr. Steel Res. 145, 386-396 (2018). https://doi.org/ 10.1016/j.jcsr.2018.02.037

72. Lu, X.; Lu, X.; Guan, H.; Zhang, W.; Ye, L.: Earthquake induced collapse simulation of a super tall mega braced frame core tube building. J. Constr. Steel Res. 82, 59-71 (2013). https://doi.org/ 10.1016/j.jcsr.2012.12.004

73. Griezic, A.; Cook, W.D.; Mitchell, D.: Seismic behavior and retrofit of outrigger beam-column frames. J. Bridge Eng. 6(5), 340348 (2001). https://doi.org/10.1061/(ASCE)1084-0702(2001)6: $5(340)$

74. Shattarat, N.K.; McLean, D.I.: Seismic behavior and retrofit of outrigger knee joints. J. Bridge Eng. 12(5), 591-599 (2007). https://doi.org/10.1061/(ASCE)1084-0702(2007)12:5(591)

75. Lee, S.; Tavor, A.: Outrigger placement in tall buildings using topology optimization. Eng. Struct. 74, 122-129 (2014). https:// doi.org/10.1016/j.engstruct.2014.05.019

76. Babaei, M.: Multi-objective optimal number and location for steel outrigger-belt truss system. J. Eng. Sci. Technol. 12(10), 2599 2612 (2017)

77. Smith, R.J.; Willford, M.R.: The damped outrigger concept for tall buildings. Struct. Des. Tall Spec. Build. 16, 501-517 (2007). https://doi.org/10.1002/tal.413

78. O'Neill, J.C.: Application of damping in high-rise buildings. M. Eng. Dissertation, Massachusetts Institute of Technology, USA (2006)

79. Smith, R.J.; Willford, M.R.: Damping in tall buildings - uncertainties and solutions. In: International Association for Bridge and Structural Engineering, Chicago (2008). https://doi.org/10.2749/ 222137908796225618

80. Chen, Z.Q.; Wang, Z.H.: A novel passive energy dissipation system for frame-core tube structure. In: The Seventh Asia-Pacific Conference on Wind Engineering, Taipei, Taiwan (2009)

81. Smith, R.: The damped outrigger - design and implementation. Int. J. High-rise Build. 5(1), 63-70 (2016)

82. Willford, M.; Smith, R.; Scott, D.; Jackson, M.: Viscous dampers come of age. Struct. Mag. 6, 15-18 (2008)

83. Chang, C.M.; Wang, Z.; Spencer, B.F.; Chan, Z.: Semi-active damped outriggers for seismic protection of high-rise buildings. Smart Struct. Syst. 11(5), 435-451 (2013)

84. Ping, T.; Chuangjie, F.; Fulin, Z.: Dynamic characteristics of a novel damped outrigger system. Earthq. Eng. \& Eng. Vib. 13(2), 293-304 (2014). https://doi.org/10.1007/s11803-014-0231-3

85. Willford, M.R.; Smith, R.J.: Performance based seismic and wind engineering for 60 story twin towers in Manila. In: The 14th World Conference on Earthquake Engineering, Beijing, China (2008)

86. Infanti, S.; Robinson, J.; Smith, R.: Viscous dampers for high-rise buildings. In: The 14th World Conference on Earthquake Engineering, Beijing, China (2008)

87. Poon, D.C.K.; Shieh, S.; Joseph, L.M.; Chang, C.: Structural design of Taipei 101, the world's tallest building. In: Proc. CTBUH 2004 Seoul Conf. Seoul, Korea, pp. 271-278 (2004)

88. Wang, M.; Nagarajaiah, S.; Sun, F.F.: Dynamic characteristics and responses of damped outrigger tall buildings using negative stiffness. J. Struct. Eng. 146(12), 04020273 (2020). https://doi.org/10. 1061/(asce)st.1943-541x.0002846

89. Sun, F.F.; Wang, M.; Nagarajaiah, S.: Multi-objective optimal design and seismic performance of negative stiffness damped outrigger structures considering damping cost. Eng. Struct. 229, 111615 (2021). https://doi.org/10.1016/j.engstruct.2020.111615

90. Chung, K.; Sunu, W.: Outrigger systems for tall buildings in Korea. Int. J. High-rise Build. 4(3), 209-217 (2015)

91. Mohamed, O.A.; Najm, O.: Outrigger systems to mitigate disproportional collapse in building structures. Procedia Eng. 161, 839-844 (2016). https://doi.org/10.1016/j.proeng.2016.08.725
92. Asai, T.; Ikago, K.; Araki, Y.: Outrigger tuned viscous mass damping system for high-rise buildings subject to earthquake loadings. In: 6th International Conference on Advances in Experimental Structural Engineering, University of Illinois, Urbana-Champaign, United States (2015). https://doi.org/10.1016/j.engstruct.2017.10. 040

93. Luo, Z.; Xue, J.; Qi, L.; Sui, Y.: Experimental and numerical study on viscously-damped outriggers with amplifying devices. J. Build. Eng. 38, 102172 (2021). https://doi.org/10.1016/j.jobe.2021. 102172

94. Spencer, B.F.; Dyke, S.J.; Sain, M.: Phenomenological model for magneto-rheological dampers. J. Eng. Mech. 123(3), 230-238 (1997). https://doi.org/10.1061/(ASCE)0733-9399(1997)123: 3(230)

95. Li, Y.; Li, J.; Li, W.; Du, H.: A state-of-the-art review on magnetorheological elastomer devices. Smart Mater. Struct. 23(12), 123001 (2014). https://doi.org/10.1088/0964-1726/23/12/123001

96. Yu, Y.; Royel, S.; Li, J.; Li, Y.; Ha, Q.: Magneto-rheological elastomer base isolator for earthquake response mitigation on building structures: modeling and second-order sliding mode control. Earthq. Struct. 11(6), 943-967 (2016). https://doi.org/10.12989/ eas.2016.11.6.943

97. Chen, X.; Li, J.; Li, Y.; Gu, X.: Lyapunov-based semi-active control of adaptive base isolation system employing magneto-rheological elastomer base isolators. Earthq. Struct. 11(6), 1077-1100 (2016). https://doi.org/10.12989/eas.2016.11.6.1077

98. Wang, Z.; Chang, C.M.; Spenzer, B.F.; Chen, Z.: Controllable outrigger damping system for higher rise building with MR dampers. In: Sensors and Smart Structures Technologies for Civil, Mechanical and Aerospace Structures, San Diego, California, United States, vol. 7647, pp. 1-8 (2010). https://doi.org/10.1117/12.847837

99. Asai, T.; Watanabe, Y.: Outrigger tuned inertial mass electromagnetic transducers for high-rise buildings subject to long period earthquakes. Eng. Struct. 153, 404-410 (2017). https://doi.org/10. 1016/j.engstruct.2017.10.040

100. Kim, H.S.; Kang, J.W.: Semi-active outrigger damping system for seismic protection of building structure. J. Asian Archit. Build. Eng. 16(1), 201-208 (2017). https://doi.org/10.3130/jaabe.16.201

101. Tan, P.; Fang, C.J.; Chang, C.M.; Spencer, B.F.; Zhou, F.L.: Dynamic characteristics of novel energy dissipation systems with damped outriggers. Eng. Struct. 98, 128-140 (2015). https://doi. org/10.1016/j.engstruct.2015.04.033

102. Lin, P.C.; Takeuchi, T.; Matsui, R.: Seismic performance evaluation of single damped outrigger system incorporating buckling restrained braces. Earthq. Eng. Struct. Dyn. 47(12), 2343-2365 (2018). https://doi.org/10.1002/eqe.3072

103. Lin, P.C.; Takeuchi, T.; Matsui, R.: Optimal design of multiple damped-outrigger system incorporating buckling-restrained braces. Eng. Struct. 194, 441-457 (2019). https://doi.org/10.1016/j.engst ruct.2019.05.078

104. Zhou, Y.; Lu, D.; Xing, L.; Aguaguiña, M.: Frequency domain analysis-based optimal configurations and energy dissipation performance of combined damped outrigger systems. Structures 31, 406-418 (2021). https://doi.org/10.1016/j.istruc.2021.01.085

105. Kamgar, R.; Saadatpour, M.M.: A simple mathematical model for free vibration analysis of combined system consisting of framed tube, shear core, belt truss and outrigger system with geometrical discontinuities. Appl. Math. Model. 36, 4918-4930 (2011). https:// doi.org/10.1016/j.apm.2011.12.029

106. Chen, P.C.; Hsu, S.C.; Zhong, Y.J.; Wang, S.J.: Real-time hybrid simulation of smart base-isolated raised floor systems for high-tech industry. Smart Struct. Syst. 23(1), 91-106 (2019). https://doi.org/ 10.12989/sss.2019.23.1.091

107. Chang, C.M.; Asai, T.; Wang, Z.; Spencer, B.F.; Chen, Z.: Smart outriggers for seismic protection of high-rise buildings. In: 15 th 
World Conference on Earthquake Engineering, Lisbon, Portugal (2012). https://doi.org/10.12989/sss.2013.11.5.435

108. Asai, T.; Spencer, B.F.: Structural control strategies for earthquake response reduction of buildings. In: Report No. NSEL-043; Newmark Structural Engineering Laboratory, Department of Civil and Environmental Engineering, University of Illinois at UrbanaChampaign, Champaign, IL, USA (2015)

109. Al-Subaihawi, S.; Kolay, C.; Marullo, T.; Ricles, J.M.; Quiel, S.E.: Assessment of wind-induced vibration mitigation in a tall building with damped outriggers using real-time hybrid simulations. Eng. Struct. 205, 110044 (2020). https://doi.org/10.1016/j.engstruct. 2019.110044
110. Asai, T.; Chang, C.M.; Phillips, B.M.; Spencer, B.F.: Real-time hybrid simulation of a smart outrigger damping system for highrise buildings. Eng. Struct. 57, 177-188 (2013). https://doi.org/10. 1016/j.engstruct.2013.09.016

111. Fang, C.; Spencer, B.F.; Xu, J.; Tan, P.; Zhou, F.: Optimization of damped outrigger systems subject to stochastic excitation. Eng. Struct. 191, 280-291 (2019). https://doi.org/10.1016/j.engstruct. 2019.04.011 